\title{
¿DESCANSA SU MAJESTAD? ApROXIMACIÓN A UNA TEORÍA POLÍTICO-EMBLEMÁTICA HISPANA DEL DESCANSO REGIO
}

\author{
José Javier Azanza López \\ Universidad de Navarra
}

Resumen: El concepto del descanso regio constituye un debate de gran interés en el ámbito político hispano de la Edad Moderna, circunstancia que obedece al hecho de que a través del mismo se abordan cuestiones que afectan a la formulación misma de la monarquía y del gobierno del Estado. Desde la teoría política, pero también desde la literatura emblemática y desde la oratoria sagrada, surgen argumentaciones en torno al descanso regio que pueden agruparse en tres grandes líneas de pensamiento: la que defiende el descanso del monarca ligado a actividades físicas e intelectuales -descanso fortalecedor-; la que concibe el descanso regio como cambio de actividad en beneficio de sus súbditos -descanso activo-; y la que niega al monarca cualquier posibilidad de descanso. Este artículo pretende ser una aproximación a un tema que ofrece múltiples posibilidades en muy diferentes áreas del conocimiento.

Palabras clave: monarquía, España, siglos XVI y XVII, teoría política, emblemática.

ABSTRACT: The concept of the king's rest is a very interesting debate in the Hispanic political field of the Modern Age, circumstance due to the fact that it raises issues affecting the very formulation of the Monarchy and the state government through it. From political theory, but also from emblem literature and sacred oratory, arise arguments about the king's rest, which can be grouped into three main lines of thought: the first one defends the rest linked to physical and mental activities strengthener rest-; the second sees the rest as change of activity for the benefit of his subjects -active rest-; finally, the third denies the king any 
chance of rest. This article tries to approach a matter which offers many opportunities in different areas of knowledge.

Keywords: Monarchy, Spain, XVI and XviI Centuries, Political Theory, Emblems.

\section{INTRODUCCIÓN: EL DESCANSO COMO NECESIDAD HUMANA}

$\mathrm{L}$ a noción del descanso reparador en toda actividad humana es un tópico que viene de antiguo, proclamada por didácticos y moralistas de todas las épocas. ${ }^{1}$ Autores grecolatinos como Homero, Sócrates, Aristóteles y Plutarco, o como Ovidio, Valerio Máximo y Séneca, hacen referencia en sus escritos a la necesidad del descanso que restablece las fuerzas y ayuda a sobrellevar los trabajos de la vida. ${ }^{2}$ El asunto se mantiene vigente en Padres de la Iglesia y teólogos medievales -San Agustín y Santo Tomás de Aquino son buen ejemplo de ello ${ }^{3}$ - y adquiere una nueva dimensión en la Edad Moderna, donde existe unanimidad casi absoluta en la consideración de que el trabajo pide descanso que permita refrenar pasiones y recuperar fuerzas. Entretenimiento y descanso se convierten así en fundamento para un mejor aprovechamiento del trabajo, máxima que debe seguirse prácticamente en todos los estamentos sociales, pues afecta por igual al labrador y al estudiante, al prelado y al militar. ${ }^{4}$

1. CARMen SAnz Ayán: «Días de regocijo y horas de entretenimiento», El mundo que vivió Cervantes, Sociedad Estatal de Conmemoraciones Culturales, Madrid, 2005, 247.

2. Homero introduce el concepto de descanso al poner una lira en manos de Aquiles, quien encontraba en la música alivio en medio de la batalla. Sócrates y Aristóteles aluden a la necesidad de descanso con vistas a reemprender el trabajo con fuerzas renovadas. Plutarco insiste en que «el descanso es el condimento de los trabajos», opinión con la que coincide Ovidio, por cuanto «el trabajo que carece a su vez de descanso no puede durar». Valerio Máximo dedica al ocio uno de los capítulos de sus Hechos y Dichos Memorables, extendiéndose en aclarar el concepto de descanso, al que deben tender no solo los indolentes sino también los animosos, para que «tras una oportuna interrupción en las ocupaciones, puedan ejercerlas con mayores bríos». Y Séneca desarrolla el mismo concepto en De tranquilitate animi: «Darse tiene algún refrigerio a los ánimos, porque descansados, se levanten mejores y más valientes al trabajo». HomERo: La Ilíada, Espasa-Calpe, Madrid, 1966, 92. Aristóteles: Ética a Nicómaco, Instituto de Estudios Políticos, Madrid, 1970, 68-69; y Política, Tecnos, Madrid, 2004, libro V, cap. 2, 168. Plutarco: «Sobre la educación de los hijos», Moralia I, Gredos, Madrid, 1992, 9c. Ovidio: Heroidas, Alianza, Madrid, 1994, 93. Publio VAlerio MÁximo: Hechos y dichos memorables. 2, Libros VII-IX, Gredos, Madrid, 2003, 95-96. LuCiO ANNEO SÉneCA: Tratados filosóficos. Cartas, Porrúa, México, 1989, 148.

3. San Agustín cita el Himno de San Ambrosio: «El descanso a los miembros cansados prepara para el trabajo, repara las mentes cansadas, y libera los pechos oprimidos por la pena». Y desarrolla los conceptos de trabajo y descanso en el Libro XIX de La ciudad de Dios. Por su parte, el Aquinita teoriza en varias cuestiones de su Suma Teológica acerca del descanso que debe dársele a alma y cuerpo para alivio de la fatiga, especialmente en la cuestión 168 de la parte II A-II AE. WALter FArrell: Guía de la Suma Teológica III. Plenitud de vida, Ediciones Morata, Madrid, 1962, 446-449.

4. Sirva como ejemplo la reflexión que, a propósito de la necesidad del descanso en el estudiante, lleva a cabo Cristóbal de Villalón en el capítulo XVII del Libro II de su obra El Scholástico. CRISTÓBAL DE Villalón: El Scholástico (ed. José Miguel Martínez Torrejón), Crítica, Barcelona, 1997, 164-169. 
Sin embargo, el tema se torna más complejo cuando se trata del descanso del monarca, dado que dejan de tener validez las pautas de comportamiento universales referidas para los casos anteriores. Todo ello desemboca en un debate de gran interés, hasta el punto de que el descanso regio se convierte en un lugar común de la literatura política hispana. A su enriquecimiento contribuirán no solo teóricos y moralistas, sino que será abordado igualmente desde ámbitos como la emblemática y la oratoria sagrada; incluso literatos como Quevedo, en su empeño por adoctrinar al monarca, reflexionan en torno al descanso regio.

Cabe preguntarse por los motivos por los que un asunto a priori menor en el conjunto de las grandes coordenadas políticas de la Edad Moderna suscita tal interés. Para tratar de encontrar una respuesta válida a este interrogante, conviene no perder de vista que el concepto de descanso regio da pie a una revisión de aspectos relacionados con las principales cualidades que deben adornar al rey, a la vez que presenta implicaciones que afectan al gobierno de sus vasallos y a la formulación misma de la monarquía. En efecto, en las reflexiones en torno al tema no faltan las teorías acerca de la concordia y unidad que debe procurar en sus estados, ni sobre el ejercicio de la justicia distributiva como virtud política mediante la cual regula la acción de repartir cargos y beneficios conforme a los méritos de sus súbditos, atajando con ello posibles descontentos que pudieran derivar en revueltas y sediciones. Permiten igualmente valorar el comportamiento del monarca en sus relaciones con ministros y consejos, en el conocimiento y trato de sus súbditos, o en su preparación para la guerra en tiempos de paz. En última instancia, a través del concepto de descanso regio se plantean cuestiones que afectan al propio sistema de gobierno, dando pie a una discusión sobre la mayor o menor idoneidad del valimiento como fórmula eficaz.

Consecuentemente, algunas de las grandes pautas de actuación política del monarca se abordan desde la perspectiva del descanso, dado que este incide en ellas en mayor o menor medida. En su planteamiento teórico, el debate resulta tan enriquecedor que no existe unanimidad, de manera que podemos agrupar los argumentos en tres líneas de pensamiento: la que defiende el descanso del monarca ligado a actividades físicas e intelectuales; la que concibe el descanso regio como prolongación del trabajo en beneficio de sus súbditos; y la que niega al monarca cualquier posibilidad de descanso. Existen no obstante infinidad de matices que propician cierta ambigüedad en algunos planteamientos, sin llegar a quedar totalmente definidos en uno u otro grupo; y aunque también con sus correspondientes excepciones, las dos primeras vías dominan el siglo XVI y los dos primeros tercios del XVII, mientras que la tercera se impone tras la muerte de Felipe IV. Es nuestro propósito ofrecer una aproximación al tema -nunca con afán de agotarlo- a través de una selección de autores y textos. ${ }^{5}$

5. Este estudio se centra en aquellos escritos que hacen referencia al monarca en el ejercicio de su gobierno, acudiendo tan solo en momentos puntuales a los tratados relacionados con la educación y aprendizaje del joven príncipe. Deseo expresar mi más sincero agradecimiento al prof. Jesús María Usunáriz Garayoa por su inestimable ayuda en la organización de los contenidos. 


\section{EL «DESCANSO FORTALECEDOR», FÍSICO E INTELECTUAL}

\subsection{El descanso recuperador como necesidad del monarca}

Gran parte de quienes teorizan acerca del descanso del monarca son partidarios del mismo, exhibiendo para ello un argumento común: el descanso reparador que aleja al rey por un tiempo prudente de los cuidados públicos, le permite volver con más fuerza al cumplimiento de sus obligaciones, y retomar sus negocios con mayor empeño y acierto. Se trata en consecuencia de un «descanso fortalecedor» que proporciona renovados bríos, al igual que ocurre con el resto de los mortales.

Ya en 1615 el Provincial de la Compañía de Jesús en el Perú, Juan Sebastián, expresaba con nitidez esta idea al afirmar que «es cosa cierta, y sabida por experiencia, que en los palacios de los Príncipes hay de ordinario algún jardín, donde ellos se recrean con los suyos, para descansar de los negocios, y tomar fuerzas, para volver a ellos con más calor». ${ }^{6}$ Otros autores se manifiestan en el mismo sentido, caso de Juan de Zabaleta, agudo y satírico cronista de la corte de Felipe IV, autor en 1666 de El Emperador Conmodo, tratado que contenía «muy artificiosa y discreta enseñanza para todos, especialmente para príncipes», refiere en su censura el jesuita Cristóbal de Ortega. También en este caso conviene en la necesidad del descanso del monarca para poder seguir trabajando, pues «el trabajo, a quien no sucede descanso, es muerte; el descanso, a quien no sucede trabajo, es ocio». Por eso el entretenimiento es medicina para el alma regia, siempre que se tome con moderación y a su debido tiempo; no en vano, «que se divierta el rey que trabaja, es regimiento vital; pero que trabaje solo en entretenerse, es vicio execrable». ${ }^{7}$

La necesidad del «descanso fortalecedor» está presente asimismo en el terreno de la emblemática, como queda de manifiesto en la Idea de un príncipe político christiano de Diego Saavedra Fajardo. Aparentemente, el diplomático murciano se muestra contrario al descanso del monarca, pues se suceden a lo largo del tratado diversas consideraciones que inducen a ello. Quizás la más significativa sea la empresa 71, Labor omnia vincit (El trabajo todo lo vence), cuya pictura protagoniza un ariete golpeando una muralla en la que ha abierto una brecha, para dar a entender al monarca que el trabajo y la constancia pueden conseguir vencer cualquier obstáculo [Fig. 1]. Ninguna dificultad embaraza al ánimo constante, afirma Saavedra, antes de concluir que «no es oficio de descanso el reinar». ${ }^{8}$ Mas no tardará en matizar su anterior

6. De el bien, Excellencias y Obligaciones de el Estado Clerical y Sacerdotal. Por el R. P. Ioan Sebastián, Provincial de la Compañía de Jesús en el Perú. En Sevilla, por Matías Clavijo, 1615, 640.

7. El Emperador Conmodo. Historia discursiva, según el texto de Herodiano... Su autor, Don Iuan de Zabaleta, Coronista del Rey N. S. En Madrid, por Andrés Garcia, 1666, 96rº-98r ${ }^{\circ}$.

8. Idea de un Príncipe Político Christiano representada en cien empresas. Dedicada al Príncipe de las Españas Nuestro Señor. Por Don Diego Saavedra Faxardo... En Monaco, 1640, 390-396. Diego SAAVEdra FajARdo: Empresas Políticas (ed. Sagrario López Poza), Ediciones Cátedra, Madrid, 1999, 805-811. 


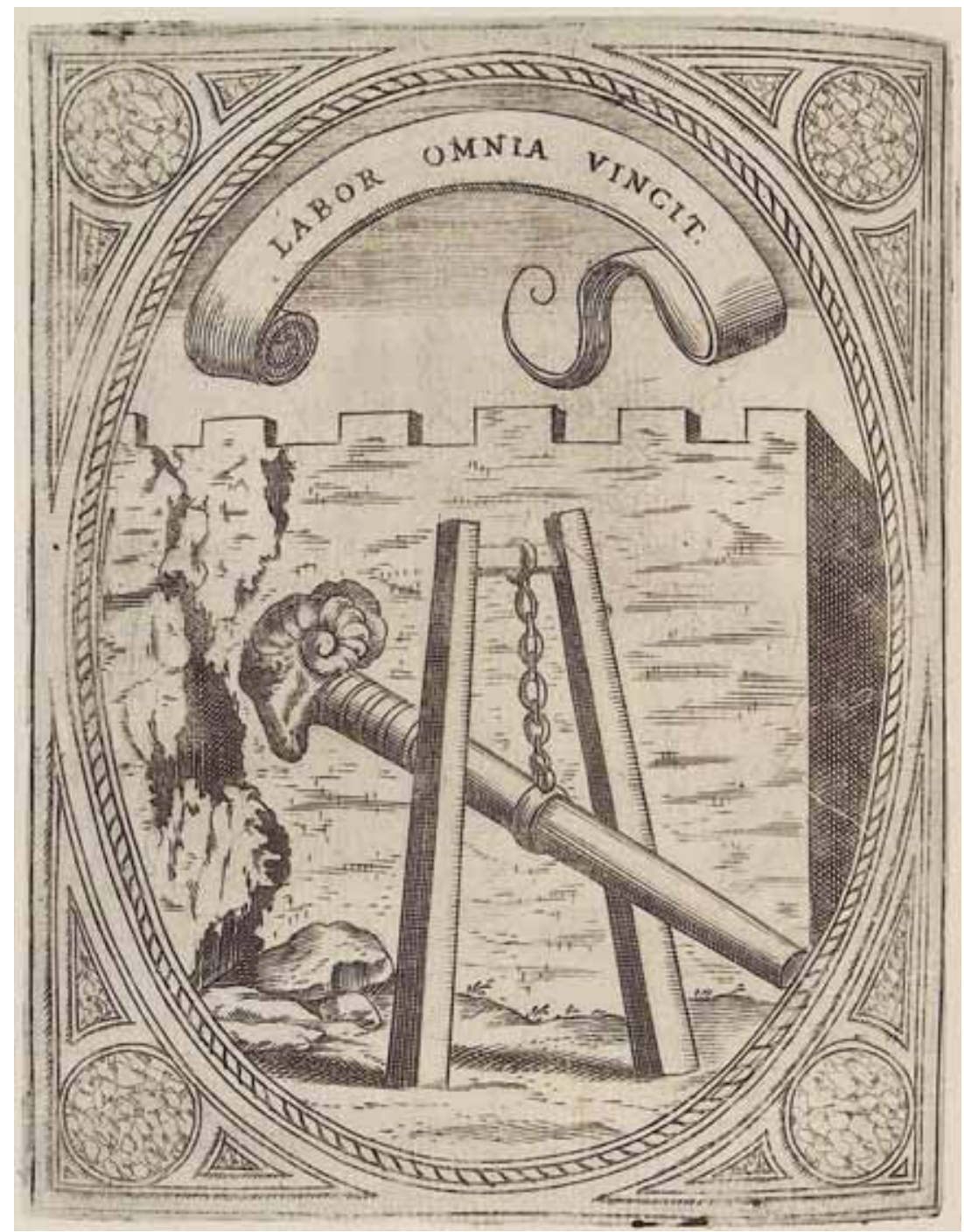

Fig. 1. Diego Saavedra Fajardo. Idea de un príncipe politico christiano.

Empresa 71: Labor omnia vincit

declaración, al reconocer que no todo puede ser trabajo en el príncipe políticocristiano, quien también deberá gozar de jornadas de alivio y descanso. Y lo hace en la empresa 72, en la que con el mote Vires alit (Alimenta su fuerza), una mano se posa sobre el caño de una fuente para impedir que surja, pero el agua, con más fuerza, se escapa entre los dedos [Fig. 2]. El descanso y el ocio, que reavivan las fuerzas, son necesarios en todo trabajo, como lo muestra el agua que, interrumpido su curso, sale con más vitalidad. ${ }^{9}$ El planteamiento

9. Idea de un Príncipe Político Christiano, 397-402. SaAvedra Fajardo, Empresas Políticas, 812-818. 


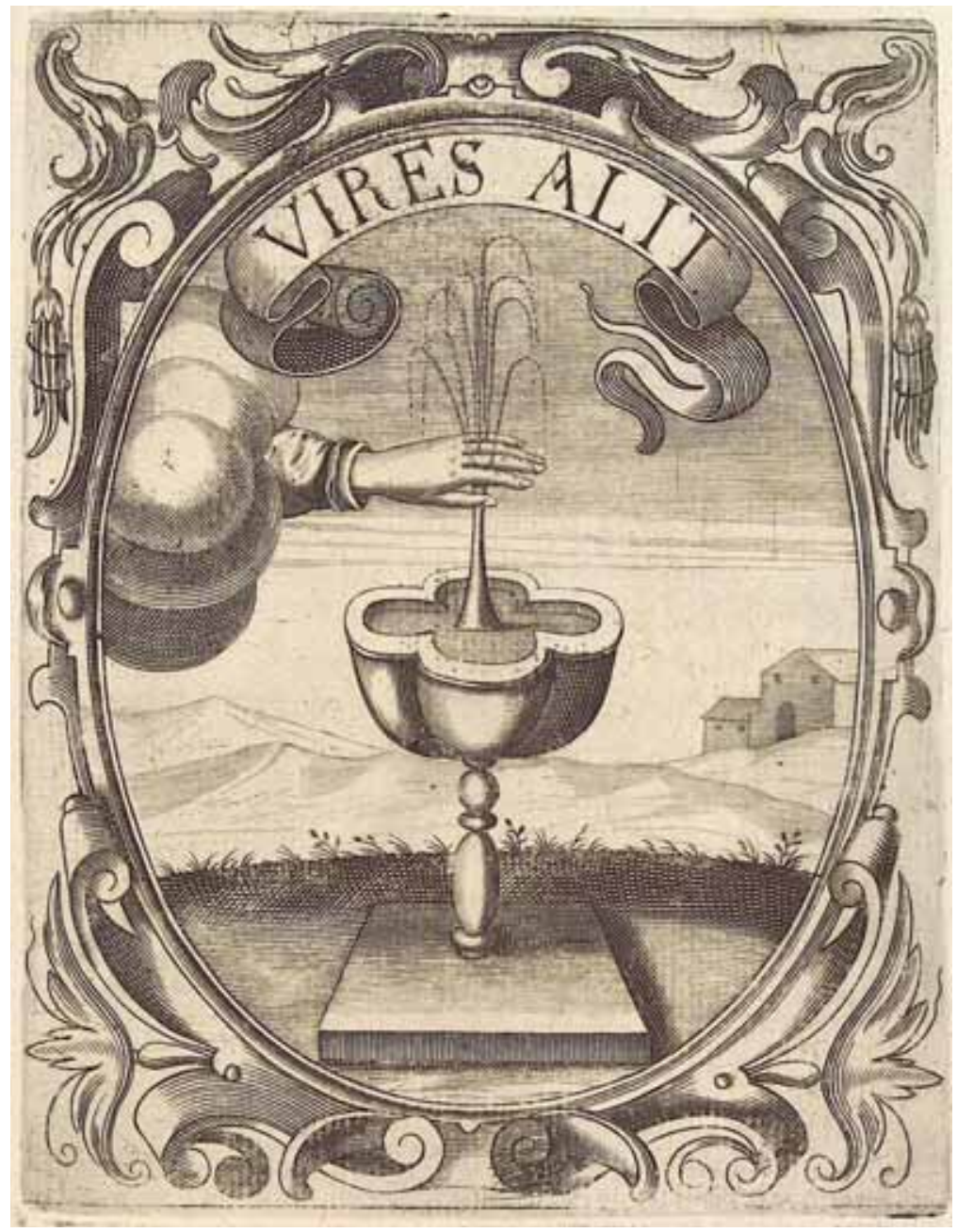

Fig. 2. Diego Saavedra Fajardo. Idea de un príncipe politico christiano. Empresa 72: Vires alit

saavedrino será seguido muy de cerca por el propio Felipe IV, como se deduce de una atenta lectura de la correspondencia regia con María Jesús de Ágreda. Se suceden en las cartas reflexiones en torno al descanso, de las que puede ser un buen ejemplo la del 6 de noviembre de 1647: «Yo vine bueno de mi jornadilla, habiendo gozado algunos días del campo; que para trabajar más es menester tomar de cuando en cuando algún alivio».10

10. Sobre la influencia que pudo ejercer la Idea de un Príncipe Político Christiano en el comportamiento de Felipe IV, basada en la correspondencia que mantuvieron el monarca y sor María Jesús de Ágreda de forma ininterrumpida entre 1643 y 1665, véase José JAVIER AzANZA LóPEZ: «An Emblematic Reading of a Regal Epistolary Exchange: Philip IV's Letters to Sister María de Ágreda, in the Light of Saavedra Fajardo», Cull, J. T. and Daly, P. M. In Nocte Consilium. Studies on Emblematics in Honor of Pedro F. Campa, Verlag Valentin Koerner, Baden-Baden, 2011, pp. 43-86. 


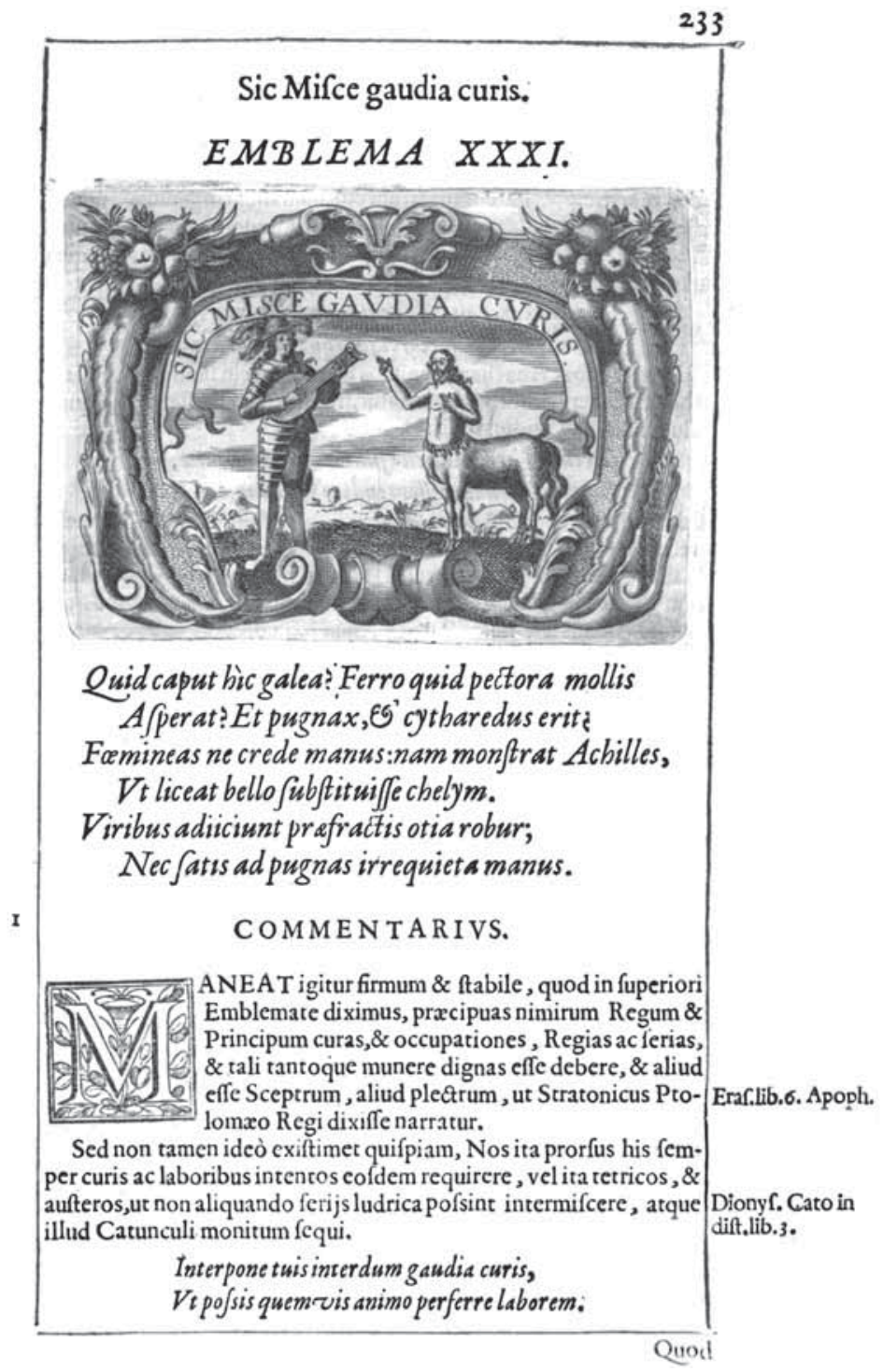

Fig. 3. Juan de Solórzano Pereira. Emblemas Regio-políticos. Emblema XXXI: Sic misce gavdia cvris

Siguiendo la doctrina de Saavedra Fajardo - a quien cita en varias ocasiones a lo largo de su razonamiento-, una postura similar adopta el jurisconsulto madrileño Juan de Solórzano Pereira en el emblema XXXI de sus Emblemas Regio-políticos; ${ }^{11}$ y, por imitación, el jesuita logroñés Andrés Mendo en el

11. D. Ioannis de Solórzano Pereira... Emblemata Centum, Regio Politica, in Centuriam Unam Redacta... In Typographia Domin. Garciae Morras, Matriti, 1653, 233-239. Jesús MARía GonzÁLEZ DE ZÁrate: Emblemas Regio-Políticos de Juan de Solórzano, Ediciones Tuero, Madrid, 1987, 133-134. 


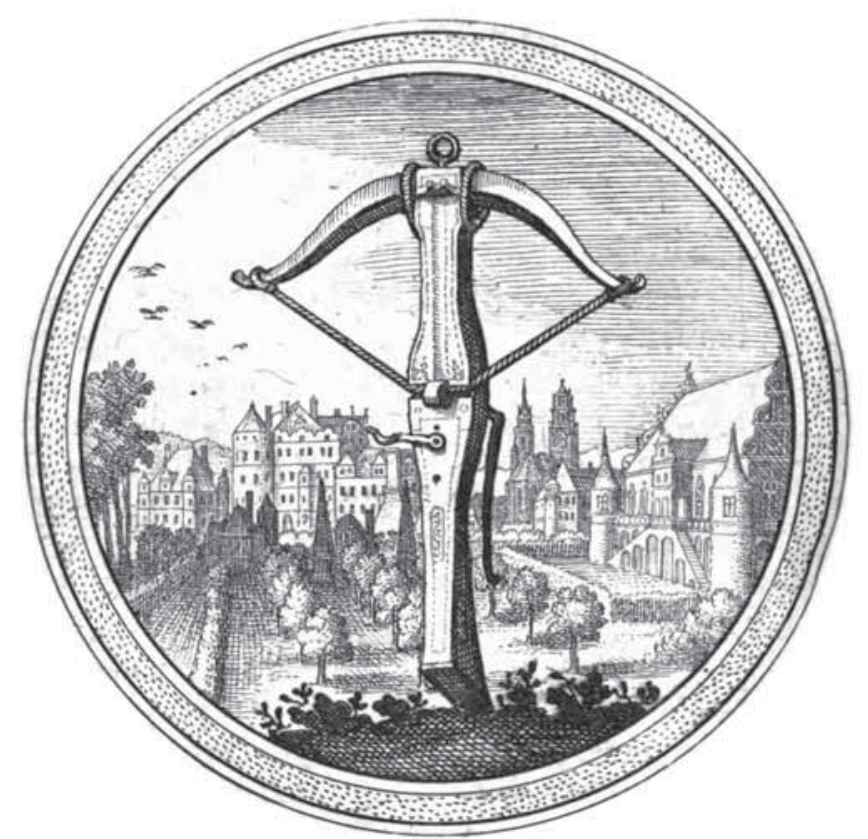

Fig. 4. Julius Zincgreff. Emblematum Ethico-politicorum Centuria. Emblema 69

Documento LXXIX de su Príncipe perfecto y ministros ajustados. ${ }^{12} \mathrm{En}$ ambos casos, el mote del emblema es el mismo: Sic misce gavdia cvris (Combina así los deleites con los trabajos); y también la pictura, que muestra al centauro Quirón enseñando a tocar el laúd a Aquiles, todavía ataviado con la indumentaria militar [Fig. 3]. La Ilíada relata cómo Aquiles recreaba su ánimo tras el combate tocando la cítara, tal y como le había enseñado Quirón, su maestro. ${ }^{13}$ Similar deberá ser el comportamiento del príncipe, quien entre tantos cuidados por su pueblo necesita disfrutar de algún descanso para poder retomar su actividad política con mayor fuerza, por cuanto no es durable el trabajo que no se interrumpe. La propia naturaleza humana pide la alternancia entre el trabajo y el descanso, y ponen varios ejemplos que pueden aplicarse a ello, como el campo de cultivo que necesita reposo para dar fruto, el caballo que para correr con ligereza no ha de marchar siempre al galope, o la nave que requiere de la reparación en el puerto para surcar velozmente los mares.

12. Principe Perfecto y Ministros aiustados, Documentos Políticos, y Morales. En Emblemas. Por el R. P. Andres Mendo, de la Compañia de Iesus... Lyon, H. Boissat y G. Remeus, 1662, 102-106. Sobre la relación entre las obras de Solórzano y Mendo, véase Ana Ma Rey Sierra: «Mendo, a la sombra de Solórzano Pereira», Estudios sobre Emblemática Española (ed. Sagrario López Poza), Sociedad de Cultura Valle-Inclán, El Ferrol, 2000, 261-271; y Beatriz Antón: «Los Emblemata Centvm Regio Politica (Madrid, 1653) de Juan de Solórzano», Imagen y Cultura: la interpretación de las imágenes como historia cultural (eds. Rafael García Mahíques y Vicent F. Zuriaga Senent), vol. I, Generalitat Valenciana, Valencia, 2008, 249-267.

13. Homero, La Ilíada, 92 
Y entre los símiles no falta el del arco cuya cuerda, en caso de permanecer continuamente tensada, acaba perdiendo su elasticidad. La imagen del arco encuentra su fuente de inspiración en los textos clásicos -Ovidio, Plutarco-y gozará de tradición emblemática como metáfora del descanso reparador en los repertorios de Guillaume de la Perrière, ${ }^{14}$ Juan de Borja, ${ }^{15}$ Sebastián de Covarrubias, ${ }^{16}$ o el propio Saavedra Fajardo entre otros. Y también se sirve de la misma Julius Zincgreff, cuyo emblema 69 de su Emblematum Ethicopoliticorum Centuria muestra en su pictura una ballesta con su arco totalmente tensado, en referencia a la necesidad del descanso del gobernante ${ }^{17}$ [Fig. 4]; imagen que recogerá más tarde Bartholomaeus Hulsius en su Emblemata Sacra. ${ }^{18}$

\subsection{Entre el ejercicio físico y la actividad intelectual}

Coincide por tanto gran parte de la teoría política en la necesidad del «descanso fortalecedor» del monarca, pues no será duradero ni efectivo el trabajo que no se interrumpe, y así su labor de gobierno mejorará tras disfrutar de una recreación moderada. Admitida esta premisa inicial, la siguiente cuestión que se plantean los autores de este grupo es la naturaleza de las actividades regias en su tiempo de ocio, considerando una doble posibilidad: el ejercicio físico, representado en la caza, las justas y torneos, y los juegos y deportes; y la actividad intelectual, ámbito en el que destacan la música, el cultivo y estudio de las letras, y la compañía de hombres doctos y eruditos.

Algunos autores aconsejan al monarca la práctica simultánea de ambos, atendiendo al tópico de «las armas y las letras» cuyo ejercicio no resulta contradictorio, sino perfectamente compatible. Así, Juan de Zabaleta no duda en afirmar que «han de tener los reyes algunos ratos de ejercicio corporal, porque sin él, o es toda la vida enfermedad, o se acorta la vida»; pero significa igualmente que «el estudio de las letras humanas es decentísimo para un Rey, si se toma por entretenimiento». ${ }^{19}$ De la misma opinión es Saavedra Fajardo, quien matiza no obstante que habrá de tenerse en consideración la edad y el tiempo en que se practiquen, para no ofender la dignidad de la majestad causando descrédito al monarca: «Cuando los años del príncipe son pocos, ningunos divertimentos mejores que los que acrecientan el brío y afirman las

14. Guillaume de la Perrière: Le Théâtre des bons engins, París, Denis Janot, 1544, Emblema XXV.

15. Rafael García Mahíques: Empresas morales de Juan de Borja: imagen y palabra para una iconología, Ajuntament de València, Valencia, 1998, 150-151.

16. Emblemas Morales de Don Sebastián de Covarrubias Orozco, Capellán del Rey N. S. Maestrescuela, y Canónigo de Cuenca, Consultor del Santo Oficio... En Madrid, Por Luis Sanchez. Año 1610, 238.

17. Julius Wilhem Zincgreff: Emblematum Ethico-politicorum Centuria, Frankfurt, Theodor de Bry, 1619, emblema 69.

18. Bartholomaeus Hulsius: Emblemata Sacra, Dat is, Eenighe Geestelicke Sinnebelden... Door B. H., Ghedruckt int' Jaer 1631.

19. El Emperador Conmodo, $4 \mathrm{r}^{\circ}-5 \mathrm{v}^{\circ}$ y $96 \mathrm{r}^{\circ}-98 \mathrm{r}^{\circ}$. 


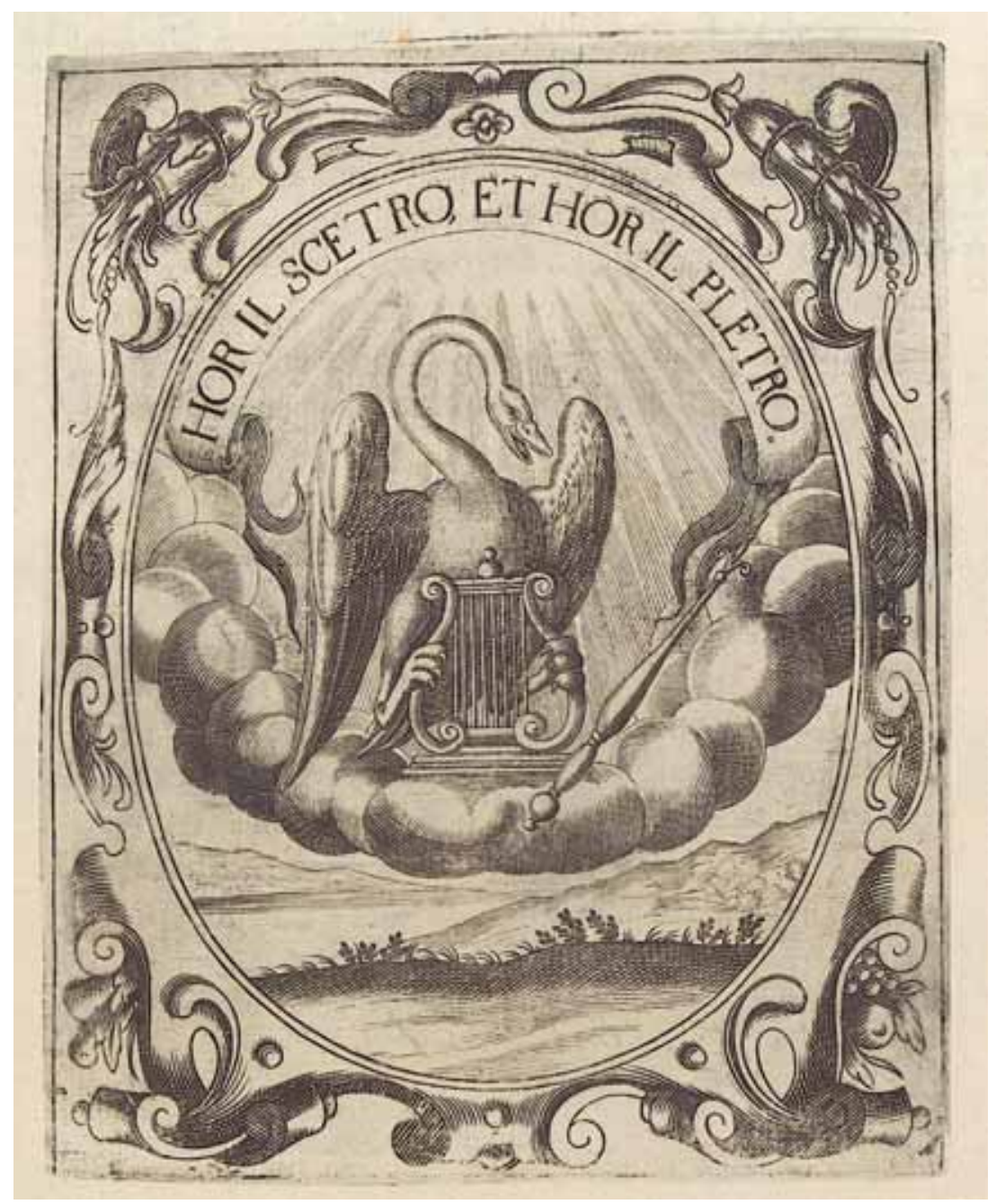

Fig. 5. Diego Saavedra Fajardo. Idea de un príncipe político christiano. Empresa 5 (ed. 1640): Hor il scetro, et hor il pletro

fuerzas, como la armas, la jineta, la danza, la pelota y la caza. También aquellas artes nobles de la pintura y la música son muy a propósito para restituir los espíritus perdidos en la atención de los negocios, como no se gaste en ellas el tiempo que piden los cuidados públicos». A la música había dedicado ya el diplomático murciano la empresa 5 de su editio princeps -en las siguientes variará- a propósito de la educación del príncipe, que con el mote Hor il scetro, et hor il pletro, mostraba un cisne (Apolo) bañado de rayos de sol sobre una nube, aferrando con sus patas una lira y con un cetro a su lado, para significar que la música era diversión apropiada por sus beneficiosas propiedades ${ }^{20}$ [Fig. 5].

20. Idea de un Príncipe Político Christiano, 33-37. SaAvedra Fajardo, Empresas Políticas, 235. 
Considera asimismo como uno de los mejores pasatiempos para recrear el ánimo la conversación con hombres versados en armas y letras, pues de ellos extraerá el rey lecciones sumamente provechosas para el gobierno de sus estados; así lo hicieron el emperador Adriano, el rey Alfonso de Nápoles, y el rey Francisco I de Francia, quien «aprendió tanto desta comunicación erudita, que aunque no había estudiado en su niñez, discurría con acierto en todas materias». ${ }^{21}$

También Solórzano Pereira y Andrés Mendo son partidarios de que el monarca alterne las actividades intelectuales y físicas en su descanso, haciendo especial hincapié en la música y la caza. ${ }^{22}$ Digno de mención resulta el papel que otorgan a esta última como preparación para el arte de la guerra, por cuanto será uno de los argumentos empleados con mayor frecuencia por quienes la defienden como actividad adecuada para el descanso regio. ${ }^{23}$ Por eso fueron numerosos los reyes y emperadores que tomaron el deporte de la caza para desahogo de sus cuidados, entre ellos Trajano, quien «no quería otro alivio, que la caza, para volver con más aliento a su desvelo, y fatigas». Y también reconoció sus utilidades Alfonso X el Sabio, pues proporcionaba salud al hacer comer y dormir bien al monarca.

Frente a quienes defienden la práctica compartida de actividades físicas e intelectuales, los hay que conceden prioridad a las primeras, por cuanto el ejercicio corporal proporciona fuerza y velocidad, agilidad y destreza. A este grupo pertenece el jurista y regidor toledano Jerónimo de Zeballos, autor en 1623 del Arte real para el buen gobierno de los Reyes, y Príncipes; pese a no descartar otras actividades loables como la música o la pintura, destaca por encima de las demás la caza, ejercicio físico propio de nobles y reyes, en la que el príncipe se deberá ejercitar "para que se enseñe a sufrir trabajos, y se divierta de los que trae consigo gobernar». ${ }^{24}$ Con el anterior coincide Diego Felipe de Albornoz, en cuya Cartilla Política y Cristiana recoge «algunas virtudes de que la majestad debe adornarse y muchos vicios de los que debe apartarse». ${ }^{25}$ Pese a mostrar su reticencia al descanso del monarca - «están ociosos los príncipes cuando toda su ocupación no es en útil de sus vasallos»-, defiende

21. Idea de un Príncipe Político Christiano, 398-401. SAAvedra FAJARdo, Empresas Políticas, 813-814.

22. «La música es recreación muy propia de Príncipes, la suavidad y dulzura de las voces deleita el ánimo, alivia las penas, templa los cuidados, entretiene los sentidos, y excita en el pecho afectos generosos. La caza también es divertimento muy decente, y heroico, porque la de fieras es ensaye de la guerra, y ejercicio del valor, y aliento... En el ejercicio de la caza se fortalecen los miembros, se conserva la salud, y se recrea el ánimo». Emblemata Centum, Regio Politica, 233-239. GonzÁlez de ZÁrATe, Emblemas Regio-Politicos, 133-134. Principe Perfecto y Ministros aiustados, 103-104.

23. Véase al respecto Alfredo Alvar Ezquerra: La caza del rey. Monterías, lances y angustias (siglos XVI-XVII), La Trébere, Madrid, 2001.

24. Arte real para el buen gobierno de los Reyes, y Príncipes, y de sus vasallos. Dirigido a la Católica Magestad del Rey don Felipe IIII... Por el Licenciado Geronymo de Zeballos... En Toledo. A costa de su Autor. Año 1623. Aforismo 102. Véase también la edición crítica con estudio preliminar a cargo de Salustiano de Dios, publicada por la Editorial de Centro de Estudios Políticos y Constitucionales en Madrid en el 2003.

25. Julián Viejo Yharrassarry: «El Sueño de Nabuconodosor. Religión y política en la monarquía católica a mediados del siglo Xviı», Revista de Estudios Políticos, n 84, 1994, 159. 
la caza no solo por los beneficios que aporta a cuerpo y mente, sino por su valor como ensayo para la guerra, pues confiere al monarca una preparación en estrategia y conocimiento del terreno, además de comprobar la valentía y valor de sus nobles. ${ }^{26}$

En términos similares se expresa el dominico Andrés Ferrer de Valdecebro en los dos tomos de su Govierno general, moral y político dedicados respectivamente a fieras y aves. Contrario al ocio y al descanso en general -véanse sus afirmaciones al respecto en los capítulos del águila, gallo, león, rinoceronte, tigre, o can-, defiende en los príncipes y señores el vuelo de la garza, del que admite es loable actividad: «Salir a volar una garza, es noble ejercicio y ocupación de príncipes, y señores. Y en esto se divierten mucho, aunque no sin excesivo gasto, por lo que cuestan los pájaros que las matan, y se les perdonaran estos, y aun gastos mayores, si entregaran el ocio siempre a $\tan$ honesto ejercicio, y ocupación ${ }^{27}$ [Fig. 6].

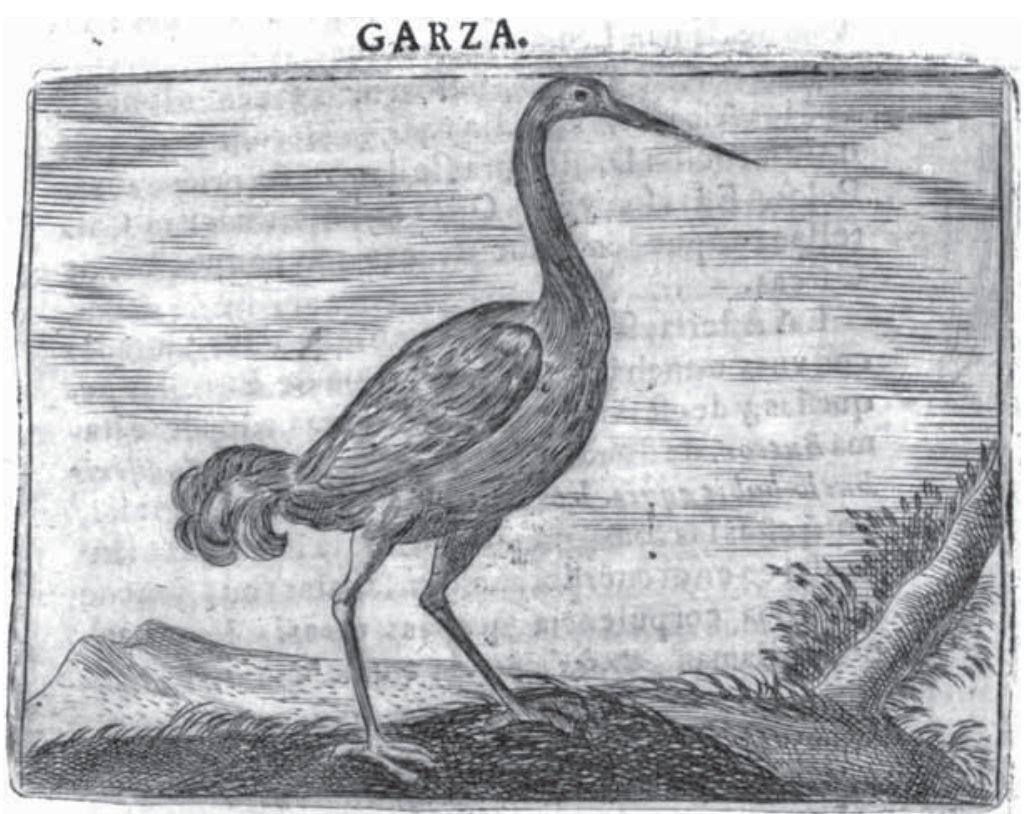

CAPIT VLO XXIIII.

Fig. 6. Andrés Ferrer de Valdecebro. Govierno general, moral y político hallado en las Aves más Generosas y Nobles. Capítulo XXIV: Garza

26. Cartilla politica y christiana. Ofrécela a los pies del Rey Nuestro Señor: D. Diego Felipe de Albornoz, Tesorero, y Canónigo de la Santa Iglesia de Cartagena. En Madrid, Por Melchor Sánchez, Año 1666, 64vº$66 \mathrm{v}^{\circ}$.

27. Govierno General, Moral, y Político hallado en las aves más generosas, y nobles... Le escrive el Padre Fray Andrés Ferrer de Valdecebro... En Madrid, en la Imprenta de Bernardo de Villa-Diego, Año de 1683, 144-145. Dicha actividad se inscribía dentro de la «altanería», que según el Tesoro de Covarrubias consistía en la «caza de volatería, por lo alto, como la del milano y la garza y la cuerva y las demás». SEBASTIÁN DE Covarrubias Horozco: Tesoro de la Lengua Castellana o Española (eds. Ignacio Arellano y Rafael Zafra), Iberoamericana, Madrid, 2006, 143. 
Junto a la caza, también los torneos resultan actividad propicia para entretenimiento físico del monarca. De esta opinión es el vallisoletano Francisco Gómez de la Reguera en sus Empresas de los Reyes de Castilla cuando en la empresa 17, carente de mote e imagen, refiere que «en la paz debe desterrarse el ocio, y dedicarse a la caza y los torneos, porque estos son, aunque tan corta hazaña, ensayos del valor para la guerra». ${ }^{28}$

Menor consideración parecen tener otras actividades como el juego de pelota, cuya práctica suscita opiniones encontradas entre los teóricos y moralistas españoles. Hay quienes lo consideran apropiado para el desarrollo físico de jóvenes y adultos, caso del médico onubense Cristóbal Méndez, quien dedica varios capítulos en su Libro del ejercicio corporal y de sus provechos - publicado en Sevilla en 1553- a ensalzar los beneficios de este y otros deportes y a recomendarlos en casos particulares.$^{29} \mathrm{Sin}$ embargo, otros autores manifiestan sus reticencias al respecto, como ocurre con Juan de Zabaleta, a cuyo juicio «ninguno de cuantos desatinos entretienen a los hombres, atormenta tanto como el juego de pelota», dado que resulta nociva para la salud al practicarse de forma inmoderada y sin las condiciones ambientales adecuadas. ${ }^{30}$ Establecida la dualidad entre partidarios y detractores del juego, autores como Juan de Mariana y Saavedra Fajardo lo incluyen entre las actividades convenientes al ejercicio del cuerpo en la educación del príncipe; pero quizás su mayor defensor sea Francisco de Zárraga, quien en el emblema 6 de su Séneca, juez de sí mismo, presenta dos manos que se lanzan mutuamente una pelota, con el mote Utrique consulendum (A una y otra cosa hay que atender) [Fig. 7]. Parte el emblemista de la necesidad humana de disfrutar de alguna recreación para alivio de los trabajos; y entre ellas considera «muy decente la del juego de Pelota, por hallar en él no solo diversión, sino saludables ejercicios del cuerpo» ${ }^{31}$. Zárraga declara que el juego de pelota es legítimo, decente y honesto, antes de hacer una serie de consideraciones técnicas según las cuales el jugador pone de manifiesto su destreza y agilidad; y aunque no hace mención explícita al monarca -sí lo recomienda a seglares y eclesiásticos,

28. Francisco Gómez de la Reguera: Empresas de los Reyes de Castilla y de León (ed. Cesar Hernández Alonso), Universidad, Valladolid, 1990. Véase también Blanca García Vega: «Las Empresas de los Reyes de Castilla y de León de Francisco Gómez de la Reguera», Actas del I Simposio Internacional de Emblemática, Instituto de Estudios Turolenses, Teruel, 1994, 93-169.

29. Cristóbal Méndez: Libro del ejercicio corporal y de sus provechos (estudio, edición crítica y notas de Eduardo Álvarez del Palacio), Universidad de León, Secretariado de Publicaciones, León, 1996; AA.VV: Cristóbal Méndez y su obra, 1553: transcripción moderna y comentarios, Instituto Andaluz del Deporte, Málaga, 1997; y Luis-PABlo Rodríguez Rodríguez, Pedro José AsIrón IrIBARREN y EduARdo Álvarez DEL PALACIO: «Estudio y comentarios sobre El libro del ejercicio corporal y de sus provechos (1553), de Cristóbal Méndez», Compendio histórico de la actividad física y el deporte (ed. Luis-Pablo Rodríguez Rodríguez), Masson, Barcelona, 2003, 213-268, dedican un interesante capítulo al ejercicio físico en Méndez.

30. Así se manifiesta Zabaleta en su obra El día de fiesta por la tarde. Obras históricas, políticas, filosóficas y morales. Escritas por Don Ivan de Zabaleta. Quinta Impresión corregida y enmendada de muchos errores... En Barcelona: en la Imprenta de Joseph Teixidó, 1704, 361-366.

31. Seneca, Juez de sí mismo, impugnado, defendido, y ilustrado. En la causa política, y moral, que litigan Don Alonso Núñez de Castro, Don Diego Ramírez del Albelda, y Don Juan Baños de Velasco y Azevedo... Por el Maestro F. Francisco de Zarraga, del Orden de San Benito... Burgos, Juan de Viar, 1684, 83-84. 
siempre que lo practiquen con moderación y sin faltar a la decencia del hábito-, las alusiones a Julio Cesar, Octavio y otros varones ilustres, parecen conceder legitimidad al hecho de que sirva como divertimento regio. ${ }^{32}$

Otros emblemistas destacan la naturaleza intelectual del descanso del monarca por encima de la física, en un conjunto de actividades que no deben entenderse como pasatiempo lúdico, sino como provechoso ejercicio. Un buen grupo de teóricos se decanta por la música, circunstancia que no es de extrañar si tenemos presente que se cuenta entre las disciplinas con mayor aceptación en la formación del príncipe como futuro monarca. ${ }^{33}$ Los motivos que argumentan para ello son de muy diversa naturaleza.

Entre los afectos a la música como actividad propicia para el descanso del monarca se encuentran el jesuita Juan de Torres, autor de la Philosophia Moral de Príncipes, y Juan de Horozco y Covarrubias, para quien la música es una de las actividades que debe aprovechar el monarca en sus ratos de ocio, dado que posee propiedades curativas y puede llegar a sanar enfermedades. También lo hace el agustino Pedro de Figueroa, autor en 1647 del Aviso de principes en aphorismos politicos y morales, obra que dedicó al padre Juan Martínez,

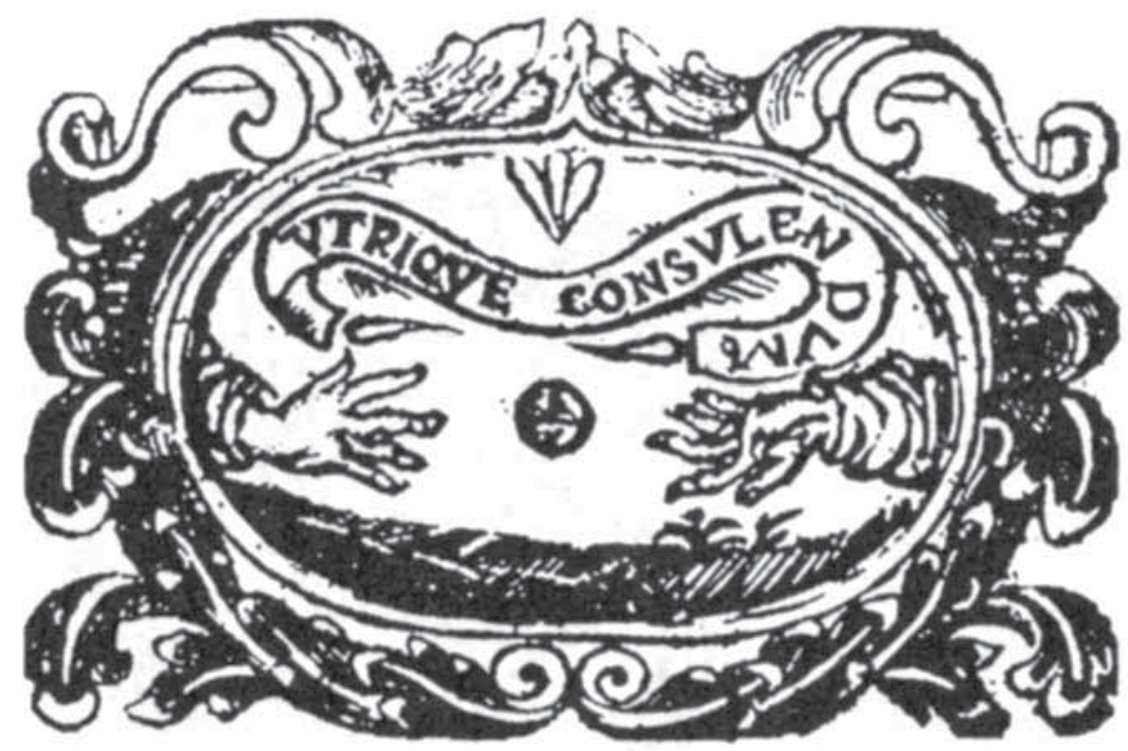

Fig. 7. Francisco de Zárraga. Séneca, juez de sí mismo. Emblema 6: Utrique consulendum

32. Sandra Ma Peñasco GonzÁleZ: «El juego en la emblemática española», Norba-Arte, vol. XXVII, 2007, 89-90.

33. Luis Robledo Estaire: «El lugar de la música en la educación del príncipe humanista», Música y literatura en la España de la Edad Media y del Renacimiento (ed. Virginie Dumanoir), Casa de Velázquez, Madrid, 2003, 1-19. 
confesor de Felipe IV. ${ }^{34}$ Figueroa se muestra en general contrario a los deleites de la recreación, tal es así que los considera uno de los cuatro vientos contra los que ha de gobernar el piloto real, junto al poder, la ambición y la lisonja; a su juicio, las delicias que proporciona el descanso disuelven el ánimo, de donde viene la destrucción de los reinos. Sin embargo, dentro de esta general negativa al descanso del monarca, admite la música como pasatiempo por sus efectos positivos. Se cuida no obstante de diferenciar - poco antes ya lo había hecho también Saavedra Fajardo- entre música sacra y profana, lanzando contra esta última una feroz crítica por sus efectos perniciosos, de manera que no debe admitirse en palacios de reyes, ni mucho menos fomentarse por quienes llevan las riendas del gobierno. Por el contrario, la música sacra tiene efectos sumamente beneficiosos con los que «se pacifica el ánimo, se expele la nociva tristeza, y se sana el tedio del entendimiento». Todo ello redundará en la paz y sosiego del monarca, quien obtendrá igualmente un beneficio espiritual; pues si la música sacra consiste en el orden y concordia de voces y notas, el demonio, que es amigo de la discordia -a él se parecen los herejes de este tiempo, que aborrecen las músicas de la Iglesia, afirma-, huirá de ella y dejará sosegada el alma regia: «la música sacra cierra la puerta al demonio, la profana se la abre», concluye el religioso. ${ }^{35}$

Coincide con las anteriores propiedades musicales el portugués Jerónimo Osorio, quien a su vez pone de manifiesto las virtudes políticas de la música, pues a través de ella el monarca podrá conocer lo importante que resulta la concordia para mantener la paz y unidad de sus reinos, al igual que la música solo conserva su armonía si todos los instrumentos suenan unidos a un mismo fin; de ahí que concluya que «la música es conveniente al príncipe, no solo para su recreación y para templar una naturaleza vehemente, sino también porque a través de las leyes que la rigen pueda entender que un estado feliz y próspero descansa en el ejercicio del orden y de la justicia» ${ }^{36}$. El descanso en este caso va más allá del mero entretenimiento o pasatiempo para convertirse en una auténtica lección sobre el arte de gobernar basada en los principios de unidad y concordia. Este testimonio de Osorio es seguido muy de cerca por Juan de Mariana en su obra De rege et regis institutione, redactada en 1590 para el futuro Felipe III, cuando afirma que «no solo ha de cultivar el rey la música para distraer su ánimo en el trabajo, sino también para que con la música comprenda que la felicidad y brillo del Estado consisten en la moderación y proporción de sus partes». ${ }^{37}$

34. Aviso de principes en aphorismos politicos y morales: meditados en la historia de Saul primer libro de los Reyes desde el cap. 8. Por el Padre Maestro Fray Pedro de Figueroa, del Orden de San Agustín... En Madrid, por Diego Díaz de la Carrera. Año 1647.

35. Aviso de principes en aphorismos politicos y morales, 207-211.

36. Hieronymi Osorii Lvsitani Episcopi Sylvensis. De Regis Institutione et Disciplina, Lib. VIII, Lysippone, Ex Officina Ioannis Hispani, 1571, 135r $\mathrm{r}^{\circ}-140 \mathrm{r}^{\circ}$.

37. JuAn DE MARIANA: La dignidad real y la educación del rey (De Rege et Regis Institutione), Centro de Estudios Constitucionales, Madrid, 1981, 185-191. 
Junto a la música se sitúan otras actividades de carácter intelectual, como la lectura, ${ }^{38}$ la escritura ${ }^{39}$ y la poesía y, en general, todo lo que supone el cultivo y estudio de las letras humanas; y también, como ya señalara Saavedra Fajardo, la conversación con eruditos de los que extraer sabias lecciones. En este punto se discute la conveniencia de que los monarcas admitan la compañía de truhanes y chocarreros para regocijo en sus momentos de descanso. El rechazo a la figura del truhán viene de antiguo, y se mantendrá como constante medieval, de manera que en los textos encauzados hacia la educación del príncipe los ataques son rotundos, y tan solo circunstancialmente son admitidos como relajo. El parámetro de comparación es el mismo de siempre: el truhán no puede dar consejo, algo que sí hace el sabio, y además su presencia resta influencia a la del consejero sobre el príncipe. ${ }^{40}$

En su Teatro del hombre, el hombre, Juan de Zabaleta parece convenir en su presencia, siempre y cuando sean de conversación ingeniosa y no inciten al vicio. ${ }^{41}$ Muy diferente es el juicio de fray Antonio de Guevara, personaje destacado de la España de Carlos V no solo en el ámbito eclesiástico, sino también en el desempeño de diferentes encargos al servicio del emperador. ${ }^{42}$ Fue autor del Relox de Príncipes, tratado de contenido político y doctrinal en el que se muestra abiertamente contrario a la truhanería al afirmar que «el príncipe debe huir como de la pestilencia de truhanes y lisonjeros». Desarrolla a continuación una extensa relación de defectos que encuentra en estas «sabandijas palaciegas», a los que acusa de ociosos y viciosos, deshonestos y maliciosos; por todo ello, su presencia no conviene a la autoridad y gravedad

38. Sobre la importancia y repercusión de la lectura en la corte, véase FERNANDo BouzA ÁLVAREZ: «Leer en palacio: de aula gigantium a museo de reyes sabios», El libro Antiguo Español III. El libro en Palacio y otros estudios bibliográficos, Ediciones Universidad de Salamanca, Patrimonio Nacional y Sociedad Española del Libro, Salamanca, 1996, 29-42.

39. Digno de mención es a este respecto el manuscrito Museo de Reyes Sabios, curiosísimo tratado escrito por el clérigo conquense Baltasar Porreño a comienzos del reinado de Felipe IV -a quien está dedicado-sobre los reyes y príncipes amantes de los libros y de la escritura. BALTASAR PorReño: Museo de los Reyes Sabios que an tenido las Naçiones del orbe y los libros que ellos y los emperadores an escrito y sacado a la luz... (Biblioteca Nacional de Madrid, Mss. 2.297).

40. Sobre el papel que truhanes y enanos desempeñaron en los palacios de los Austrias durante los siglos XVI y XVII, me remito a los trabajos de FERnANDo Bouza ÁlVAREZ: Locos, enanos y hombres de placer en la corte de los Austrias: oficio de burlas, Temas de Hoy, Madrid, 1991; y «El uso cortesano de la improporción bufonesca», Mentalidad e ideología en el Antiguo Régimen (eds. León Carlos Álvarez Santaló y Carmen María Cremades Griñán), Universidad de Murcia, Murcia, 1993, 27-36.

41. «Los reyes, y los hombres primeros en la república suelen tener en su casa truhanes. A estos es buena obra sustentarlos, como no sean maledicentes, mentirosos y deshonestos. Porque estos en lugar de recrear el ánimo, desatan la armonía de las virtudes, y desordenan el contexto de las buenas obras. El juglar ha de tener en sí mismo la gracia, y no la ha de andar a buscar en los vicios. Siendo desta manera es justo tenerle, y sinrazón maltratarle». Obras históricas, políticas, filosóficas y morales. Escritas por Don Ivan de Zabaleta, 10 .

42. Para la figura de fray Antonio de Guevara, me remito a la introducción de Emillio Blanco al Relox de Príncipes. Antonio de Guevara: Relox de Príncipes (estudio y edición de Emilio Blanco), ABL Editor, Madrid, 1994, XI-LXXVII. 
del príncipe, que debe inclinarse a la virtud y no ser convidado al vicio en su propio palacio. ${ }^{43}$

Idéntico posicionamiento muestra el erudito vallisoletano Baltasar Álamos de Barrientos en su Tácito Español, una traducción de toda la obra del historiador romano con el propósito de servir a príncipes, consejeros y ministros en su labor de gobierno, y con la que inaugura una nueva corriente teórica, el tacitismo, de la que se convertirá en uno de sus máximos exponentes. ${ }^{44}$ Entre los múltiples asuntos que trata no falta el descanso regio, del que en ocasiones parece mostrarse contrario, pues "propio es del Príncipe, vivir siempre en trabajo y fatiga ${ }^{45}$ Sin embargo, concede la necesidad de recreación al monarca, con tal que esta sea en la compañía de sabios que lo instruyan a la vez que divierten: «Los Príncipes es justo que tengan algún entretenimiento por alivio de los cuidados; pero serán más perfectos, si éstos no fueren de truhanes, ni gente infame; sino de personas de letras, y buenas artes; que junto con el entretenimiento enseñen» (Annales, Libro IV, Aforismo 343). ${ }^{46}$ Es más, una de las imágenes que decoran el bello frontispicio - no exento en su conjunto de cierta carga crítica, atendiendo a las circunstancias personales del autor durante el reinado de Felipe II- representa de forma gráfica este pensamiento, al mostrar el consejo de los sabios al príncipe mediante un conjunto de libros abiertos al espectador, entre los que se encuentran la Biblia, Tucídides, Polibio, Tito Livio y, evidentemente, Tácito [Fig. 8]. Acompañan la escena dos sentencias de Tiberio extraídas respectivamente de los Libros III y II de los Annales que completan el significado: en la parte superior, «El Príncipe no puede conocer todas las cosas con su sabiduría» (Annales, Libro III, cap. 69); y en la inferior, «Más cosas se consiguen con el consejo, que con la fuerza» (Annales, Libro II, cap. 26). El aforismo de Baltasar Álamos de Barrientos será recogido décadas más tarde por el tacitista aragonés Antonio de Fuertes y Biota en su obra Alma o Aphorismos de Cornelio Tacito. ${ }^{47}$

43. Libro Aureo del gran Emperador Marco Aurelio. Con el Relox de Príncipes. Compuesto por el Muy Reverendo, y Magnífico Señor Don Antonio de Guevara, Obispo de Guadix, Predicador y Coronista del Señor Emperador Carlos Quinto... En Madrid, por Carlos Sánchez, Año de 1650, 282-286. GuevarA, Relox de Príncipes, 917-928.

44. A partir de los escritos de Tácito, Álamos de Barrientos busca la manera de reducir la política a un conjunto de reglas o proposiciones generales a las que denomina aforismos para construir, sistemáticamente y con sorprendente economía, una ciencia del arte de gobernar. Véase a este respecto el estudio preliminar de J. A. Fernández Santamaría en Baltasar Álamos de Barrientos: Aforismos al Tácito Español, Centro de Estudios Constitucionales, Madrid, 1987, XI-CXLVII. Y también Beatriz Antón Martínez: El Tacitismo en el siglo XVII en España: el proceso de la «receptio», Universidad de Valladolid, Valladolid, 1991.

45. Álamos de Barrientos, Aforismos al Tácito Español, 257.

46. Álamos de Barrientos, Aforismos al Tácito Español, 326. La sentencia surge a propósito del comentario que hace Tácito acerca del escaso acompañamiento que llevaba el emperador Tiberio al partir de Roma, entre los que eran la mayoría «hombres sabios en las artes liberales; y casi la mayor parte dellos Griegos, para aliviar sus cuidados con hablar, y entretenerse con ellos». Tacito Español. Ilvstrado con Aforismos por Don Baltasar Alamos de Barrientos. Dirigido a Don Francisco Gomez de Sandoval y Rojas Duque de Lerma... En Madrid por Luis Sánchez a su costa y de Iuan Hasrey, Año de 1614, 237.

47. Alma o Aphorismos de Cornelio Tacito. Publicala Don Antonio Fuertes y Biota, natural del Reyno de Aragón... En Amberes, en Casa de Jacobo Mervsio, Anno 1651, 609. 


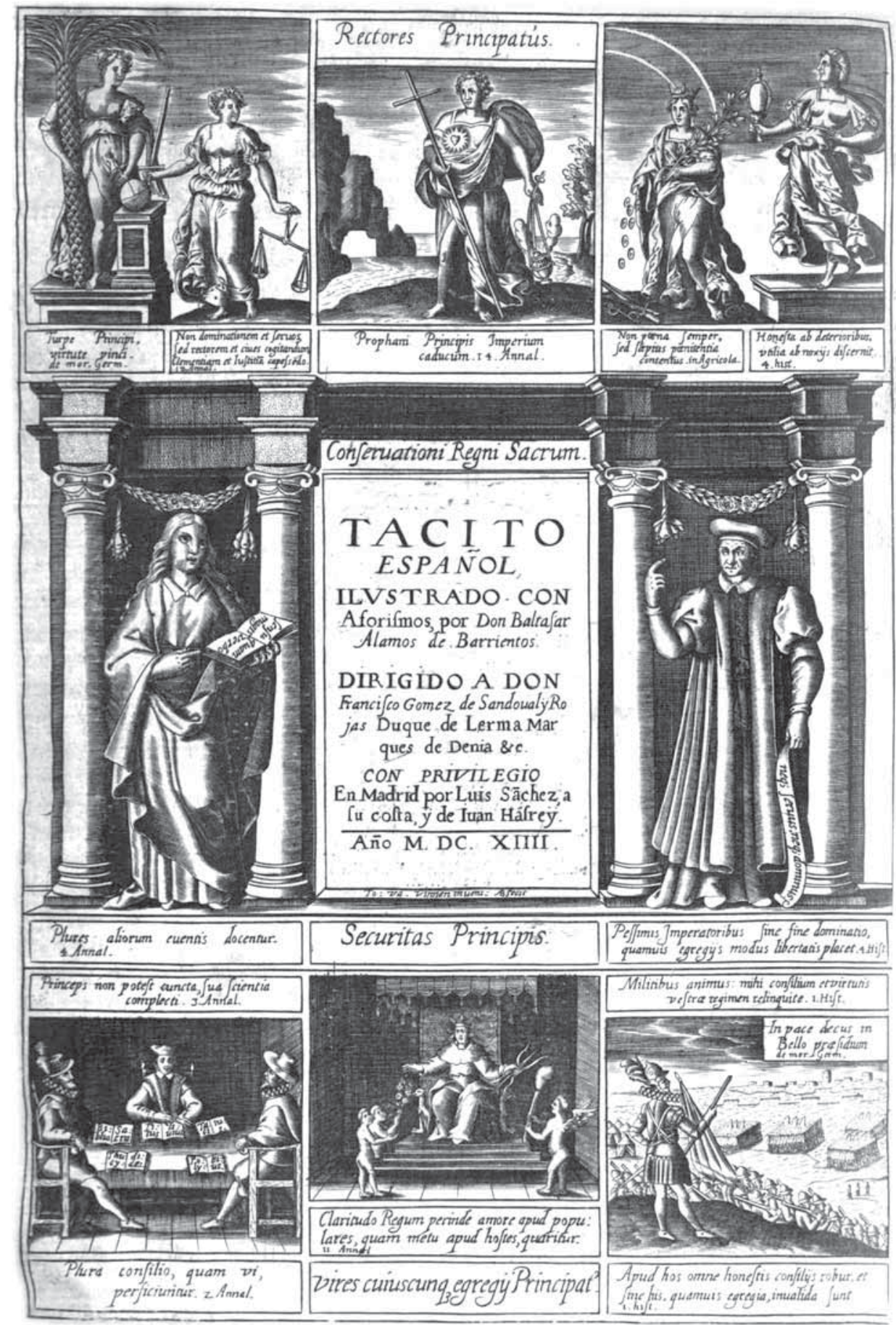

Fig. 8. Baltasar Álamos de Barrientos. Tácito Español. Grabado de portada 
Entre los contrarios a la presencia de bufones y truhanes como compañeros del monarca en sus momentos de ocio se encuentra igualmente Jerónimo de Zeballos. ${ }^{48}$ Y también Saavedra Fajardo, quien lamenta «la asistencia a las mesas de los príncipes de bufones, de locos y de hombres mal formados», para volver a recordar una vez más la conveniencia de que sean hombres doctos quienes acompañen al monarca. ${ }^{49}$ Sin embargo, la mayor crítica a la presencia de gentes poco dignas que sirven únicamente de diversión, pero que no son útiles al buen gobierno, proviene de Juan de Horozco y Covarrubias, quien dedica íntegramente al tema el emblema XLIX del Libro II de sus Emblemas morales. La pictura, que carece de mote, muestra al centauro Quirón tocando la lira, mientras dos ángeles portan sendos blasones en alusión al momento en que entrando Júpiter a reinar, le juraron por mayor todos los dioses e hicieron maravillosas demostraciones de contento, en especial Apolo con su música; pero el rey encontró particular entretenimiento en las carreras y relinchos de Quirón, con la consiguiente ofensa para los demás [Fig. 9]. Teme Horozco que, al igual que Júpiter, también el monarca conceda carta de verdad a las opiniones que vierten estos personajes y se deje guiar por ellos en sus decisiones de gobierno, llevándole al desatino. Por tal motivo, conviene alejarlos de la corte: «Los que solían admitirse otros tiempos con nombre de truhanes o chocarreros, no es justo se consientan... lo mejor es que no los haya, que son peligrosos todos; pues otros entretenimientos puede haber para alivio de las ocupaciones ordinarias de tanto cuydado y pesadumbre como tienen los Príncipes»..$^{50}$

Sorprende que entre las actividades propuestas para el descanso regio no existan apenas referencias al teatro, dado el auge que alcanzó en la corte durante los siglos XVI y XVII. ${ }^{51}$ Tenemos constancia de que validos y cortesanos relevantes organizaron y costearon de su propio bolsillo espectáculos teatrales para alivio del monarca en medio de sus obligaciones. ${ }^{52}$ Sin poder extendernos

48. Arte real para el buen gobierno de los Reyes, y Príncipes, y de sus vasallos, 7-8. BouzA, Locos, enanos $y$ hombres de placer en la corte de los Austrias, 72.

49. «Si los despropósitos de bufones divierten, ¿cuánto más divertirían las sentencias bien ordenadas de hombres doctos, que no sean severos y pesados, sino que sepan acomodarse al tiempo con graciosos y agudos chistes y motes? Espías públicas de los palacios son los bufones, y los que más estragan sus costumbres, y aún los que suelen maquinar contra las vidas, y estados de los Príncipes». Idea de un Príncipe Político Christiano, 399. SaAvedra Fajardo, Empresas Políticas, 815.

50. Emblemas Morales de Ivan de Orozco y Covarrubias, Segovia, Juan de la Cuesta, 1589, 97r ${ }^{\circ}-98 \mathrm{v}^{\circ}$.

51. El fenómeno teatral cortesano durante los siglos XVI y XVII ha sido estudiado por Carmen Sanz Ayán en numerosos trabajos, entre los que destacamos «Representar en Palacio: Teatro y fiesta teatral en la Corte de los Austrias», Reales Sitios, n 153, 2002, 28-43; «Felipe IV y el teatro», Felipe IV: el hombre y el reinado (coord. José Alcalá-Zamora y Queipo de Llano), Real Academia de la Historia, Centro de Estudios Europa Hispánica, Madrid, 2005, 269-290; y Pedagogía de reyes: el teatro palaciego en el reinado de Carlos II, Real Academia de la Historia, Madrid, 2006. Véase también para el período cronológico que nos ocupa MARGARET RICH CREER y J. E. VAREY: El teatro palaciego en Madrid: 1586-1707. Estudio y documentos, Tamesis, Londres, 1997.

52. Un buen ejemplo de ello eran las representaciones de la noche de San Juan organizadas por Olivares durante su periodo de valimiento, como parte de un plan consistente en distraer al rey de la tareas de gobierno, hacerle olvidar la difícil situación del país, y mostrar abiertamente el poder del monarca. Kazimierz SAbik: El teatro de corte en España en el ocaso del Siglo de Oro (1670-1700), Universidad de Varsovia, Cátedra de Estudios Ibéricos, Varsovia, 1994, 22. 


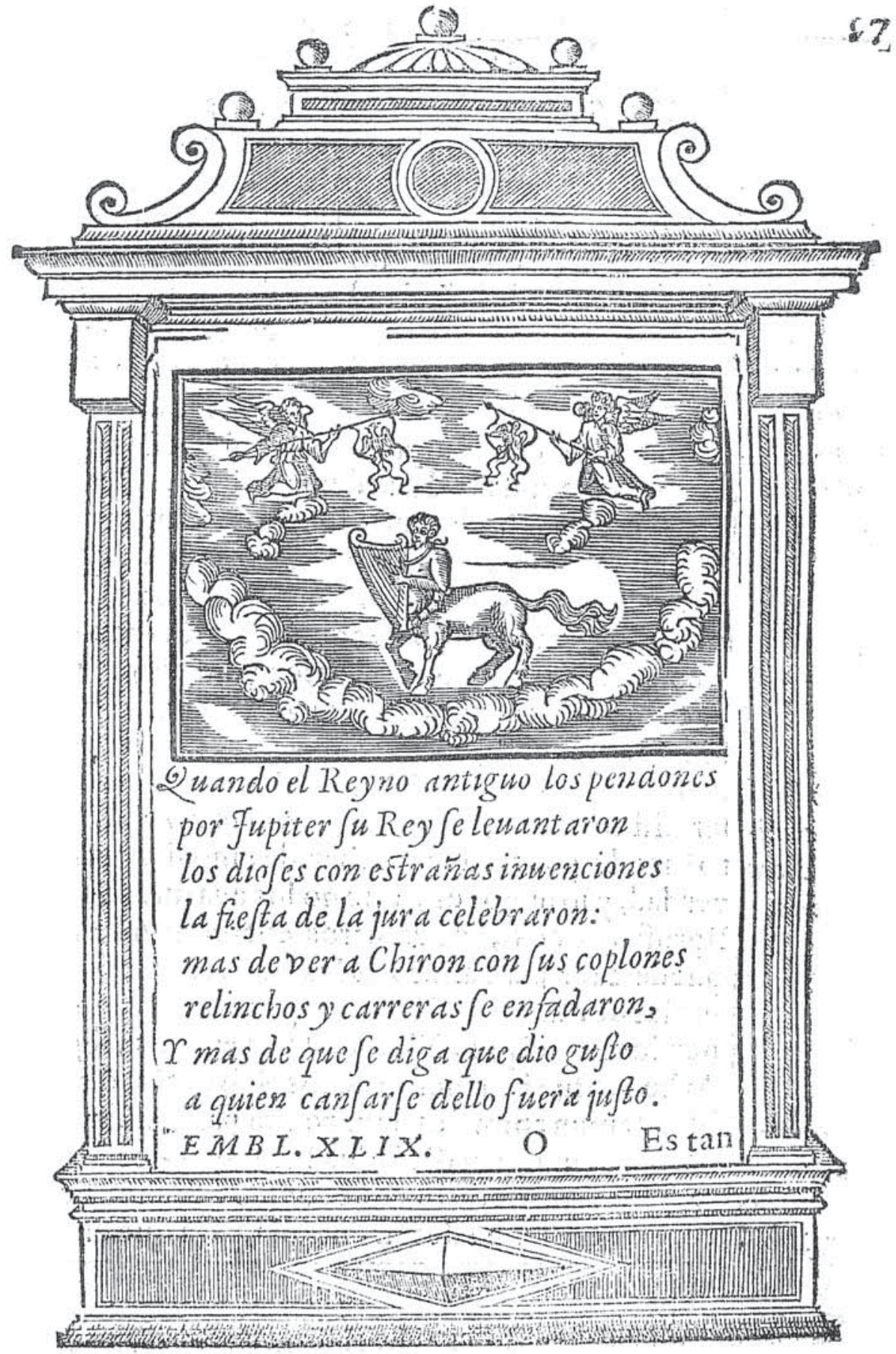

Fig. 9. Juan de Horozco y Covarrubias. Emblemas morales. Libro II, emblema XLIX 
en la complejidad del fenómeno teatral palaciego con su rico entramado ideológico-político, debemos significar que, frente a quienes lo defienden por su valor pedagógico como instrumento educativo para los jóvenes monarcas - es el caso de Juan de Zabaleta en El Emperador Conmodo ${ }^{53}$-, buena parte de los teóricos y moralistas se muestran cautos, cuando no lo atacan abiertamente por considerarlo «despertador de espíritus lascivos y vanas ociosidades», en expresión de Pedro de Figueroa. ${ }^{54} \mathrm{~A}$ estas voces discrepantes en el ámbito moral se unirán, en el marco de la crisis financiera en que desemboca el siglo XVII, las de quienes consideraban la actividad teatral palaciega como entretenimiento poco edificante que generaba cuantiosas pérdidas, tanto del tiempo que el monarca debía invertir en el gobierno de sus súbditos, como del dinero que debía destinarse a asuntos más graves y no a fastuosas e inútiles tramoyas.

\subsection{La especificidad del descanso regio y sus cualidades}

Como hemos podido comprobar, los autores que coinciden en la necesidad del «descanso fortalecedor» del monarca, difieren en la actividad que a su juicio resulta más adecuada para que al retomar el trabajo este proporcione fruto redoblado, debatiéndose entre las de naturaleza física e intelectual; pero en lo que están de acuerdo de manera prácticamente unánime es en la actitud con la que el rey debe afrontar los momentos de alivio. Y así, el legítimo descanso se tomará con moderación, teniendo presente el monarca que no es su verdadero oficio, pues este radica exclusivamente en el arte de gobernar; de manera que el supuesto de un rey retirado a una «estudiosa ociosidad»-en expresión de Savedra Fajardo- es considerado como negligencia, pues jamás debe desatender los negocios de la monarquía. Y será conforme a la edad y dignidad reales, sin que suponga menoscabo a la autoridad del monarca y al esplendor y decoro de la monarquía, ni mucho menos ponga en riesgo su integridad física o haga peligrar su vida; no en vano, en una sociedad jerarquizada en la que todo está reglamentado con arreglo a la pertenencia a un estrato social, el rey no puede rebajarse a practicar actividades consideradas de inferior rango.

En su Philosophia Moral de Príncipes, Juan de Torres se muestra explícito en cuanto a la forma en que el monarca debe afrontar las actividades de su descanso, en especial la música. Deberá hacerlo «con mucha moderación, por entretenimiento permitido a la naturaleza cansada, para alivio de sus trabajos: no para ocupación perpetua y oficio de altos corazones». Por tal motivo, no debe entrar en competencia con otros sobre quién lo hace mejor, ya que semejante actitud rebaja su categoría regia: «No es oficio de Reyes, ni les está también preciarse de músicos, que les convenga dar jamás muestra de

53. El Emperador Conmodo, $33 \mathrm{v}^{\circ}-35 \mathrm{r}^{\circ}$

54. Aviso de principes en aphorismos politicos y morales, 209-211. 
lo que entienden»..$^{55}$ En parecidos términos de moderación se expresa Juan de Zabaleta al afirmar que «el oficio del rey es gobernar hombres, este es el que ha de saber con suma perfección; lo demás lo ha de aprender con tal templanza, como si fuera culpa saberlo. Saber reinar bien, y saber bien otras facultades, no parece que se pueden abrazar con una inteligencia». Y cuando se pregunta por las actividades físicas más adecuadas para el monarca en su descanso, si bien no llega a concretar, establece un conjunto de normas de aplicación general: que sean acordes con la edad del príncipe; decentes a la dignidad que requiere, de tal manera que el monarca no quede reducido a la categoría de un hombre ordinario; y carentes de riesgo o peligro, pues «ninguna necesidad mete a los hombres en ejercicio que esté totalmente fuera de su inclinación». ${ }^{56}$ Moderación y prudencia aconseja también Jerónimo de Zeballos, dado que, aunque los reyes practiquen loables ejercicios en sus momentos de descanso, «no se han de preciar de ellos sino de los documentos del arte de gobernar, que es ciencia propia de reyes y de príncipes». ${ }^{7}$

Baltasar Gracián, en El Político, retrato panegírico de Fernando el Católico considerado por su autor como un verdadero tratado de política, ${ }^{58}$ advierte al monarca que el descanso debe hacerse atendiendo a los negocios y ocupaciones, para concluir que «fueron muchos grandes Reyes, no tanto por sus grandes prendas, quanto por su loable asistencia». ${ }^{59}$ Y Diego Felipe de Albornoz abunda en la anterior opinión e insiste en que, incluso en sus ratos de ocio, el rey debe estar pendiente de sus obligaciones, pues «también en el campo le buscan los negocios, las consultas, y los despachos, de manera que aun para descargarse del gobierno esté siempre gobernando». Ejemplo de esta actitud fueron Carlos V, Felipe II, y el recién fallecido Felipe IV, quien «en el repartimiento que tenía hecho de las horas, apenas le quedaban las muy limitadas para el descanso», tal es así que incluso cuando disfrutaba de algunas jornadas de alivio cazando, despachaba los asuntos de su propia mano, refiere Albornoz. ${ }^{60}$ En efecto, el propio Rey Planeta corrobora en más de una ocasión este descanso sin perder de vista los negocios en sus cartas a sor María Jesús de Ágreda. ${ }^{61}$

55. Philosophia Moral de Príncipes: para su buena crianza y govierno; y para personas de todos estados... Compuesta por el padre Iuan de Torres, de la Compañía de Iesus... Impresso en Barcelona: en Casa de Sebastian de Cormellas, 1598, 230-234.

56. El Emperador Conmodo, $4 \mathrm{r}^{\circ}-5 \mathrm{v}^{\circ}$ y $96 \mathrm{r}^{\circ}-98 \mathrm{r}^{\circ}$.

57. Arte real para el buen gobierno de los Reyes, y Príncipes, y de sus vasallos, 104.

58. Xavier Gil Pujol: «Baltasar Gracián: Política de El Político», Revista Pedralbes, n 24, 2004, 117-182.

59. Obras de Lorenzo Gracian, divididas en dos Tomos... En Amberes, en Casa de Geronymo y Iuan Baut. Verdussen, 1669, 516.

60. Cartilla politica y christiana, $64 \mathrm{v}^{\circ}-66 \mathrm{v}^{\circ}$.

61. Así, en noviembre de 1648 el monarca se encuentra en El Escorial, «donde hay muy buenos campos y caza, con que me divierto algo sin faltar a los despachos»; en enero de 1651 comunica a la religiosa su deseo de «irnos al Pardo por algunos días, que para este tiempo es sitio muy a propósito, y como está cerca de aquí no se hará falta en los negocios»; y en parecidos términos se expresa en diciembre de 1656, al indicar que «en pasados los Reyes, nos iremos al Pardo, a gozar algunos días de aquel Sitio; que, como no es más de dos leguas de aquí, no se hace falta a los negocios, y respiraré un poco en el campo, aunque los cuidados no dejan gozar con alivio ningún divertimento». Azanza López, «An Emblematic Reading of a Regal Epistolary Exchange». 


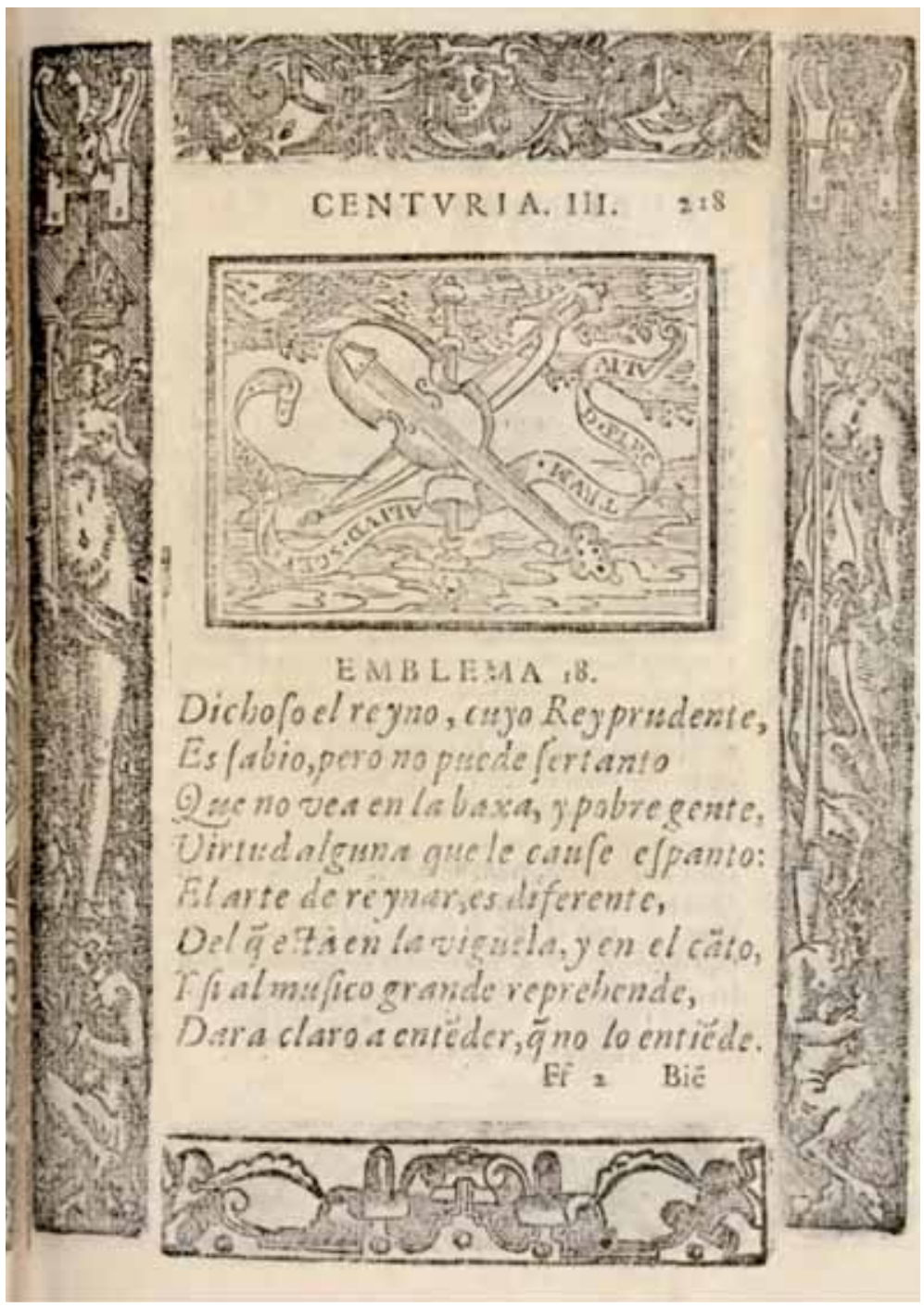

Fig. 10. Sebastián de Covarrubias. Emblemas morales. Libro III, emblema 18: Aliud plectrum aliud sceptrum

En el ámbito de la emblemática, digna de mención es la reflexión de Sebastián de Covarrubias en el emblema 18 del Libro III de sus Emblemas morales. Con el mote Aliud plectrum aliud sceptrum (Una cosa es el plectro, otra el cetro), muestra su pictura una vihuela y su arco dispuestos en aspa, detrás de los cuales figura un cetro real [Fig. 10]. Mediante este último quiere significar que el rey debe saber ante todo gobernar, porque esa es su verdadera misión; y aunque no está de más que dedique un tiempo a divertimentos ajenos a su condición regia -artes mecánicas y liberales, como la música-, lo hará con moderación y sin convertirse en un experto en dichas materias, pues 
es sabiduría que le aparta de su verdadero cometido. ${ }^{62}$ Por su parte, Saavedra Fajardo se extiende en consideraciones sobre la dignidad y nobleza de los pasatiempos del monarca, y recuerda a su vez que el reposo del príncipe ha de ser sobre los mismos negocios, los cuales no deberá perder de vista en ningún instante; así actuaron el rey Manuel de Portugal, quien aun en sus momentos de descanso concedía audiencias, y Fernando el Católico, quien «cuando salía de caza, tenía los oídos atentos a los despachos que le leía un Secretario, y los ojos al vuelo de las garzas». ${ }^{63}$ Por último, Solórzano Pereira y Andrés Mendo se aplican a diferenciar entre descanso fortalecedor y ocio desaprovechado, de manera que cuando el rey practique la caza, deberá hacerlo con moderación, ya que «es vituperable en los Príncipes la demasía en este ejercicio, pues les faltaría tiempo para asistir al gobierno»; e introducen una consideración de tipo económico al significar que deben evitarse gastos excesivos en la caza, por cuanto en muchas ocasiones corren a costa de los empobrecidos labradores, y no parece bien que el monarca destine a su divertimento lo que debiera ser para socorrer las necesidades de sus súbditos. ${ }^{64}$

\section{EL «DESCANSO ACTIVO» COMO SERVICIO ÚTIL A SUS SÚBDITOS}

Una segunda corriente de pensamiento coincide con la anterior en el punto de partida, es decir, en la necesidad del descanso del monarca; sin embargo, este es entendido como cambio de actividad dentro de los negocios regios, de manera que redunde en beneficio y utilidad de sus súbditos. Se trata de autores representativos de unas teorías que plantean una visión de la monarquía en la que destacan las obligaciones por encima de los derechos o poderes, tal es así que proponen descansar del trabajo con más trabajo, por lo que podemos hablar con propiedad de un «descanso activo».

Frente a la postura de la Historia como «maestra de la vida» defendida por algunos teóricos ya mencionados, llama la atención ahora el hecho de que con suma frecuencia se propone a Cristo como modelo de conducta -en menor medida pueden ser otros personajes bíblicos, como Moisés, Josué o David-, lo cual se convierte en buena prueba del cambio experimentado por algunos espejos de príncipes ya desde la segunda mitad del siglo XVI, donde las reglas abstractas o el ejemplo de monarcas pretéritos se perciben como insuficientes para aleccionar en la tarea de gobernar, y ejemplifican en el Maestro acciones que tienen un componente cercano a concepciones de la

62. Emblemas Morales de Don Sebastián de Covarrubias Orozco, 218.

63. Idea de un Príncipe Político Christiano, 400-401. Saavedra Fajardo, Empresas Políticas, 816.

64. Emblemata Centum, Regio Politica, 233-239. GonzÁlez de ZÁrate, Emblemas Regio-Políticos, 133-134. Principe Perfecto y Ministros aiustados, 105-106. Sobre las repercusiones negativas de las fiestas y otras actividades, denunciadas por arbitristas y pensadores que ven en ellas una de las causas de la decadencia española, véase Josefina CAstilla Soto: «La otra cara de la fiesta: algunas de sus posibles repercusiones económicas», Espacio, Tiempo y Forma, Serie IV, Historia Moderna, t. 10, 1997, 99-118. 
política como arte de Estado. El «descanso activo» del monarca se autoriza así mediante exempla evangélicos, donde la eficacia del argumento proviene de la resonancia que implica la contextualización bíblica. Circunstancia sin duda a tener en cuenta en todas sus posibilidades, dado que podría plantear una lectura e interpretación de la pintura religiosa -por ejemplo, la que decoraba las estancias del Alcázar, o de los Sitios Reales- en clave ideológico-política, de manera que, al contemplar visualmente las escenas de la vida de Cristo, el monarca asimilase un conjunto de preceptos a la luz de la teoría política de la época y encaminados al buen gobierno de sus estados.

En 1616, el franciscano Juan de Santa María, capellán de Felipe III y confesor de su hija la infanta Margarita, dedicaba al monarca su Tratado de la República y policía cristiana. Para Reyes y Príncipes. ${ }^{65}$ Con esta obra, el religioso pretendía proporcionar al rey una normativa para regir y gobernar sus estados, si bien no podemos obviar que se convierte asimismo en feroz diatriba contra la privanza del Duque de Lerma, al proponer una radical revisión del concepto de valimiento tal como lo había impuesto la práctica del reinado filipino. ${ }^{66} \mathrm{Se}$ sirve del exemplum como herramienta para la argumentación, de manera que a lo largo de las páginas del tratado los exempla sagrados conviven con los profanos. ${ }^{67}$

Entre los conceptos que desarrolla Santa María en torno al modelo del buen gobernante, no falta el del descanso del monarca, que apoya en ejemplos extraídos de textos sagrados como el Eclesiastés y el Segundo Libro de Samuel, con el relato de la historia de David y Betsabé. El religioso admite como punto de partida la necesidad del descanso regio; ahora bien, el monarca deberá saber discernir con nitidez la conveniencia de cada momento, pues no parece oportuno que mientras los reinos se ven asolados por guerras, hambres o epidemias, sus gobernantes se entreguen a pasatiempos. Asentada esta premisa inicial, Santa María desconfía de los deleites temporales que solo proporcionan disgusto, pesadumbre y tristeza de espíritu; conviene por tanto evitar juegos y regocijos mundanos o, en todo caso, tomarlos con mucha moderación, pues no hallará el rey en fiestas y comedias su verdadero descanso. ¿Dónde lo hará,

65. Tratado de República y policía cristiana. Para Reyes y Príncipes: y para los que en el govierno tienen sus vezes. Compuesto por Fray Iuan de Santa Maria, Religioso Descalço de la Provincia de San Joseph, de la Orden de nuestro glorioso Padre San Francisco. En Barcelona. Por Sebastian Cormellas. Año 1616.

66. En efecto, el tratado fue promovido por sor Margarita de la Cruz, hija de la emperatriz María, quien había dado sobradas muestras de su hostilidad hacia el duque de Lerma. La habilidad del autor al estructurar los temas y las críticas, y la existencia de un grupo cortesano que cuestionaba el poder de Lerma, dio a la obra una enorme actualidad y su publicación produjo un impacto cuyos ecos se habrían de sentir en años venideros, al punto que fray Juan de Santa María pasó a ser el «intelectual» de la oposición, requerido por todos los que trataron de acabar con Lerma, e incluso por Olivares ya en 1621. JEAN VILAR: «Conciencia nacional y conciencia económica. Datos sobre la vida y la obra del doctor Sancho de Moncada», Sancho de Moncada, Restauración política de España, Instituto de Estudios Fiscales, Madrid, 1974, 17-18. Antonio Feros Carrasco: El Duque de Lerma: realeza y privanza en la España de Felipe III, Marcial Pons, Madrid, 2002, 422-426.

67. VICTORIA PINEDA: «La tradición del exemplum en el discurso historiográfico y político de la España Imperial», Revista de Literatura, LXVII, $\mathrm{n}^{\circ}$ 133, 2005, 43. 
entonces? A su juicio, la recreación del monarca radica en aquellas actividades que lo hacen virtuoso y que no se prestan al remordimiento de conciencia ni a la murmuración de sus súbditos; y estas no son otras que las del cumplimiento de su oficio: conceder audiencias, escuchar a los agraviados, proveer los oficios y despachar los negocios. El modelo del buen gobernante será por tanto aquel que convierte sus momentos de ocio en una prolongación de su propia labor como rey, sin delegar en manos ajenas que le puedan restar fama y usurpar méritos ante sus vasallos, reflexión en clara sintonía con sus planteamientos contrarios al valimiento. ${ }^{68}$

La anterior formulación del descanso regio entendido como actividad encaminada a mejorar el gobierno de sus súbditos, es defendida igualmente por otros tratadistas de la época, caso del jurisconsulto toledano Juan Vela, hombre de dilatada experiencia judicial y en el manejo de negocios públicos tanto en la corte como en Indias. En 1675 vio la luz su Política Real y Sagrada, obra dirigida a Carlos II con el propósito de «idear un Príncipe Católicamente Político para lograr los mayores aciertos de su Reinado», pensamiento de reminiscencia saavedrina que recoge en el prólogo. ${ }^{69}$ Su magnífica portada, obra del grabador Pedro de Villafranca, condensa gráfica y conceptualmente una conducta basada en las virtudes cristianas y políticas, convirtiéndose en un magnífico testimonio en torno al ideal monárquico ${ }^{70}$ [Fig. 11]. Articula Vela su obra en doce discursos que tienen un denominador común: son las acciones de Cristo las que guían al monarca para asegurarle el mayor acierto de su reinado. En efecto, el autor constata la existencia de una multitud de libros que tratan sobre la política de príncipes, algunos de ellos sumamente perniciosos como los de Maquiavelo, ${ }^{71}$ Erasmo o sus discípulos, otros ciertamente muy aprovechables para llegar a ser un buen político; pero tan solo en el Evangelio se hallará la doctrina segura para convertirse en un político perfecto, a la luz de la fe. En consecuencia, Cristo es propuesto como modelo para que el rey católico sepa cómo debe actuar en el gobierno de sus vasallos, en la elección y conservación de sus ministros y validos, en las relaciones con unos y otros, y en tiempos de paz y de guerra; y no falta una alusión al descanso del monarca, sirviéndose para ello de un ejemplo tomado del Evangelio: la curación del paralítico en la piscina probática (Juan 5, 1-9), que protagoniza el Discurso VIII.

68. Tratado de República y policía cristiana, 160-166.

69. Política Real y Sagrada. Discurrida por la vida de Iesuchristo, Supremo Rey de Reyes. Que sus Sagrados Coronistas delinearon en los Sacrosantos Evangelios. Para el Govierno de los Príncipes, elección y acierto de los ministros de sus Reynos. Ofrécela al Excelentísimo Sr el Sr D. Pedro Portocarrero el Licdo D. Ivan Vela... En Madrid: En la Imprenta Imperial: Por Joseph Fernandez de Buendía. Año de 1675.

70. Adolfo CARrasco Martínez: «El príncipe deliberante abstracto. Debate político en torno al rey y la Monarquía de España (1680-1700)», Carlos II. El rey y su entorno cortesano, Centro de Estudios Europa Hispánica, Madrid, 2009, 83.

71. De hecho, Vela dedica buena parte de su Discurso XII a atacar a Maquiavelo, huyendo de política tan abominable. Antonio Álvarez de Morales y Constantino García: «Crisis del Aristotelismo y Razón de Estado en España», Historia y Comunicación Social, 1, Universidad Complutense, Madrid, 1996, 156. 


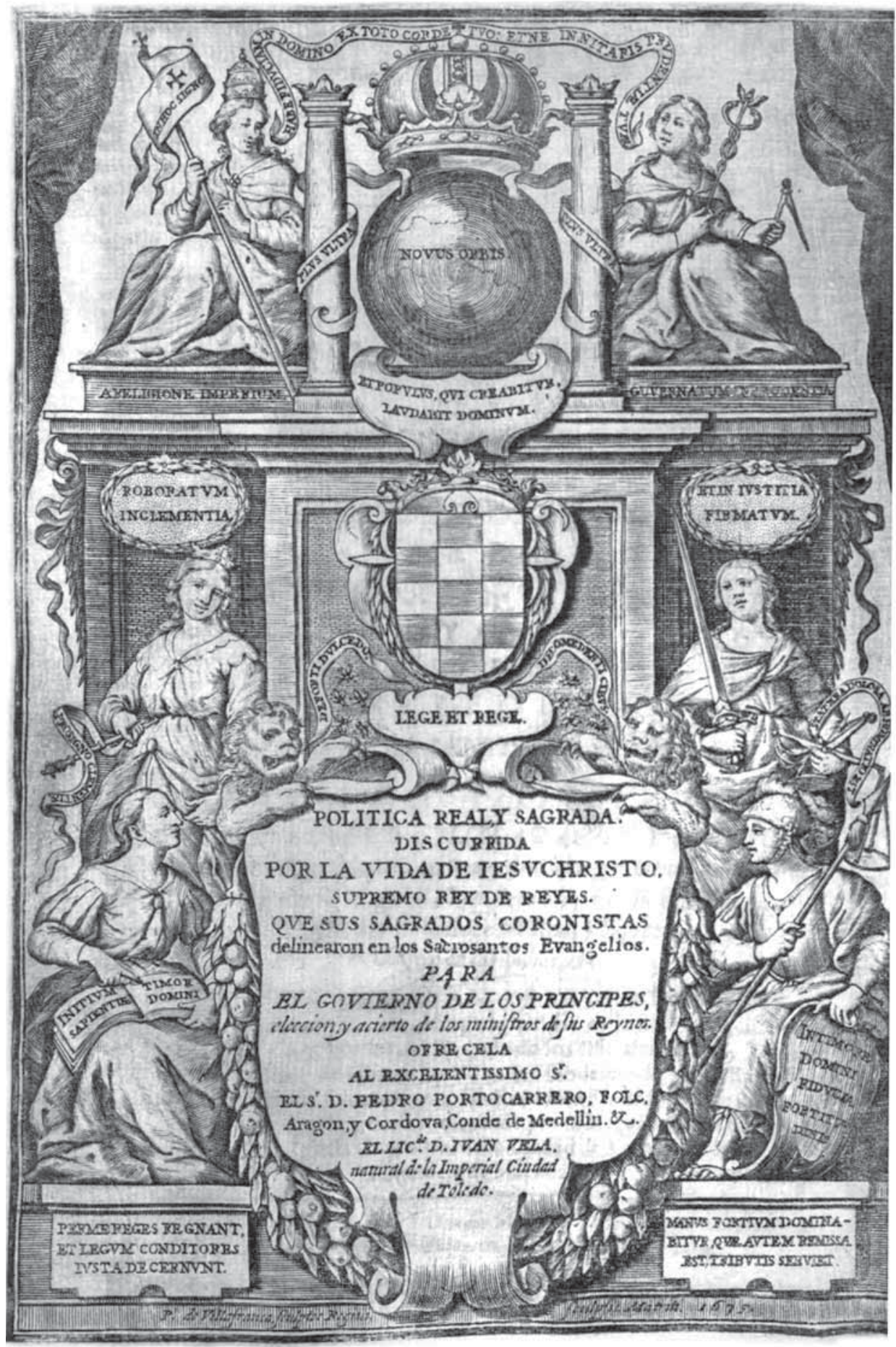

Fig. 11. Juan Vela. Política Real y Sagrada. Grabado de portada 
$\mathrm{Al}$ inicio del pasaje, Cristo se dirige a Jerusalén para celebrar una de las fiestas judías. Pudiera pensarse que el Señor va a dedicar su tiempo de descanso a regocijos y entretenimientos, pero no es así; mientras los demás se divierten, el Rey de Reyes se aplica a curar dolencias y remediar calamidades. Del anterior episodio debe extraer el monarca varias conclusiones. La primera de ellas, que el monarca tendrá sus momentos para el ocio, pues no debe estar en perpetua obligación, y descansar durante un tiempo es tomar aliento para seguir. Disponga por tanto el monarca de sus períodos de descanso; pero no se abandone en ellos a la diversión de los sentidos que pongan en peligro su fama y honra de rey. Es más, critica severamente al ministro que -aun con buena intención- aparta al monarca de su obligación y lo distrae de las fatigas de su cargo, guiándolo por los falsos deleites del mundo. Por el contrario, el descanso del príncipe debe ser diligente estudio para ver y detectar con sus propios ojos -y no a través de ajenos- las necesidades de sus vasallos y las dolencias de su reino, y aplicarse a remediarlas con urgencia; esta es la obligación del que gobierna, a imitación de Cristo en la piscina probática.

Dentro de este planteamiento general, asevera Vela que será buen descanso y discreta diversión el desvelo del príncipe en leer los libros donde se encuentran anotados los méritos singulares de sus súbditos, para que no queden estos sin premio. Insiste con vehemencia el jurisconsulto en la trascendencia del reparto de mercedes y beneficios como basa y fundamento principal para engrandecer el crédito real; tal es así que el concepto de descanso es entendido en términos de generosidad y justicia distributiva, por cuanto «nada puede ser tan decoroso a los Príncipes, y tan útil a las provincias», al atraer hacia sí el afecto de sus súbditos, y evitar de esta manera posibles descontentos en el seno de la monarquía. ${ }^{72}$ Se trata de un asunto de gran trascendencia en el contexto político de la época, pues a juicio de un nutrido grupo de teóricos la supervivencia de la monarquía dependía de la capacidad del rey para estar atento al mínimo atisbo de desunión o confrontación entre sus colaboradores por motivos de injusticias; solo él podía impedir sediciones, dado que las guerras domésticas ocasionaban de ordinario la mayor ruina. ${ }^{73} \mathrm{Al}$ mismo asunto aludía ya el agustino Juan Márquez a comienzos del siglo XVII en El Gobernador christiano deducido de la vida de Josué, al aconsejar al príncipe que adoptase en su descanso una actitud vigilante encaminada a descubrir y premiar la lealtad de sus súbditos, sin abandonarse a entretenimientos, juegos y festines en detrimento de los negocios de Estado. ${ }^{74}$

72. Politica Real y Sagrada, 265-343.

73. Adolfo Carrasco Martínez: «Los grandes, el poder y la cultura política de la nobleza en el reinado de Carlos II», Sudia. Historica. Historia Moderna, vol. 20, 1999, 77-136.

74. El Gobernador Christiano deducido de la vida de Josué, Príncipe del Pueblo de Dios, Por el R. P. M. Fr. Juan Márquez, de la Orden de S. Agustín, Predicador de S. M. el Rey D. Felipe III... Nueva Sexta Impresión... Madrid, 1773, en la Imprenta, y Librería de D. Manuel Martín, 81-82. 
El planteamiento de Juan Vela que muestra a Cristo como supremo guía del monarca en el gobierno de sus estados no falta en la oratoria sagrada, donde son innumerables los ejemplos que podemos citar al respecto. El «descanso activo» del monarca encaminado a satisfacer las necesidades de su pueblo es puesto de manifiesto por el lusitano Antonio Ferreira en un sermonario que, como indicaba el mercedario Gabriel de Losada en su aprobación de la obra, a su labor doctrinal acompañaba la política, por cuanto «decorosamente informa a los Príncipes para el acierto de sus gobiernos». En uno de sus sermones, Ferreira nos aproxima al relato evangélico en el que Jesús se sentó en un monte con sus discípulos para descansar; pero viendo la necesidad que padecía la muchedumbre, de inmediato se aprestó a socorrerlos, obrando la multiplicación de panes y peces (Juan 6,1-15). También el monarca debe buscar en sus fatigas descanso, templando el trabajo con el ocio; mas siguiendo el ejemplo del Señor, que actuó como rey atendiendo a los suyos incluso en los momentos de descanso, el ocio del príncipe jamás será sin utilidad del vasallo. En consecuencia, el rey deberá aplicarse en su tiempo de descanso a satisfacer el bien común, pues en ello consiste la potestad real. ${ }^{75}$

Más explícito se muestra si cabe el jesuita Juan Rodríguez Coronel, predicador real que durante la regencia de Mariana de Austria demostró su elocuencia en laudatorios sermones a la reina, cuya predicación sincera y valiente le valió sufrir las iras de los privados y el destierro en sus propias carnes. ${ }^{76}$ En 1670 se dirigía desde el púlpito de la Capilla Real a un Carlos II todavía niño, a quien trataba de instruir acerca del oficio de reinar a propósito del pasaje evangélico de Cristo y la samaritana (Juan 4, 1-42) que acababa de proclamar. Era su primera reflexión para constatar la existencia de numerosos volúmenes para instrucción de príncipes que llevaban por título Relox de Príncipes, significando con ello sus autores que sus máximas eran las más precisas para asegurar el acierto regio; pero esta propiedad tan solo correspondía a Cristo, celestial relox de príncipes «porque les advierte acerca de cómo conservar la corona, y alcanzar la corona de la gloria». ${ }^{77}$

Asentada la doctrina de Cristo como ejemplo para el monarca, conviene Rodríguez Coronel en la necesidad del descanso regio; no en vano el propio Maestro se sentó junto a un pozo para aliviar la fatiga del camino, actitud con la cual autorizó las horas de recreo a los príncipes. Tengan estos pues algún momento de ocio, pero sea siempre después de haber atendido audiencias,

75. Advertencias nuevas a la letra y moralidad de los Evangelios de Quaresma, miércoles, viernes y domingo. Por el Doctor Antonio Ferreira, de nación Lusitana... Libro Pósthumo. Tomo Primero... En la imprenta de María de Quiñones. Año de 1657, 359-379.

76. Félix Herrero Salgado: La oratoria sagrada en los siglos XVI y XVII, Fundación Universitaria Española, Madrid, 1996, 304-305. Antonio Álvarez-Ossorio Alvariño: «Facciones cortesanas y arte del buen gobierno en los sermones predicados en la Capilla Real en tiempos de Carlos II», Criticón, 90, 2004, 104.

77. Sermones exornatorios y de Quaresma, que predicó el Reverendissimo Padre Juan Rodríguez Coronel, de la Compañía de Jesús, Predicador de Su Majestad, a los Señores Reyes, en su Real Capilla, y en los Templos en que asistieron sus Majestades. Tomo Segundo... En Madrid: Por Juan García Infançon. Año 1695, 12-25. 
despachos y consultas, pues descansar del descanso merece grave censura. Ahora bien, mal se aviene con la corona el descanso cuando este no es sino para delicias y ostentaciones vanas, asevera el predicador real. ¿A qué debe destinar en consecuencia el rey sus momentos de ocio? De nuevo el relox celestial indica el camino a seguir, ya que Cristo dedicó su descanso a emprender una nueva y más urgente tarea, como fue la salvación del alma de la samaritana. Así, también el descanso supremo de un monarca será mudar de trabajo para iniciar otro mayor; el recreo del rey no será ocioso e inútil, sino provechoso para sus súbditos mediante el estudio y adopción de medidas encaminadas a la paz y concordia en sus reinos, que es el mayor bien para la salvación de la república. En definitiva, el relox celestial de Cristo no es tan tirante como para que la cuerda quiebre o las pesas se rompan, sino que permite al monarca sus horas de descanso; pero será descanso de un trabajo con otro, buscando el beneficio de sus vasallos y no el suyo propio.

No era sin embargo Rodríguez Coronel el primero en servirse del pasaje evangélico de Cristo y la samaritana para teorizar acerca del descanso del monarca. A lo largo de la primera mitad del siglo xviI, Francisco de Quevedo había ido dando forma a su Política de Dios, gobierno de Cristo y tiranía de Satanás (con este título aparece en sus primeras ediciones ${ }^{78}$ ), obra cuyo asunto central es el ejercicio del poder por parte del rey, a quien se le presenta como un recetario político-moral en su «oficio de regir»; y aunque las dos partes que componen el tratado corresponden a épocas distintas en la vida y visión quevedianas, la estrategia esencial de ambas es muy semejante, apoyada en la autoridad de Cristo como modelo incuestionable para el monarca ${ }^{79}$ [Fig. 12]. Según Quevedo, cifrado en la naturaleza ejemplar del Maestro se encuentra un lenguaje que el rey debe aprender a descifrar y practicar, lo cual pone de manifiesto uno de los aspectos centrales de la Política: el ejercicio del poder como imitatio, la idea de imitación política basada en la ejemplaridad de Cristo, sobre la que el literato madrileño elabora un «léxico» del arte de gobernar. ${ }^{80}$

Exhorta el autor a asumir por entero el oficio regio sin descargar en validos su obligación, con continuas advertencias sobre las causas del declive

78. Véanse por ejemplo las ediciones milanesa y barcelonesa de 1626, y la pamplonesa de 1631.

79. Como significa Fernández Mosquera, «la Política de Dios se asienta sobre la analogía de CristoPríncipe cristiano y sobre esta base Quevedo establece los sentidos políticos de los textos sagrados, incluso con interpretaciones fácilmente detectables como circunstanciales y ad hoc que en los años de la primera parte de la obra se dirigen claramente hacia el reinado de Felipe III y sus validos, como en la segunda están destinados a ilustrar el valimiento de Olivares y el reinado de Felipe IV». Santiago Fernández MosquerA: «El sermón, el tratado, el memorial: la escritura interesada de Quevedo», La Perinola, 2, 1998, 70. Véase también al respecto William h. Clamurro: «Quevedo y la lectura política», La Perinola, 5, 2001, 95-107.

80. Se trata de un asunto que encierra una compleja dimensión ideológica, de la que se ocupa CARMEN Peraita: Quevedo y el joven Felipe IV: el príncipe cristiano y el arte del consejo, Kassel, Reichenberger, 1997; «La copia erasmiana y la construcción retórica de la Política de Dios», La Perinola, 3, 1999, 209. 224; «Paradigmas y monarcas: el contexto del ejemplo y el rechazo de la Historia en la Política de Dios de Quevedo», Estudios de filología y retórica en homenaje a la Profesora Luisa López Grigera, Universidad de Deusto, Bilbao, 2000, 355-369; y «La oreja, lengua, voz, el grito y las alegorías del acceso al rey; elocuencia sacra y afectos políticos en Política de Dios de Quevedo», La Perinola, 5, 1999, 185-205. 


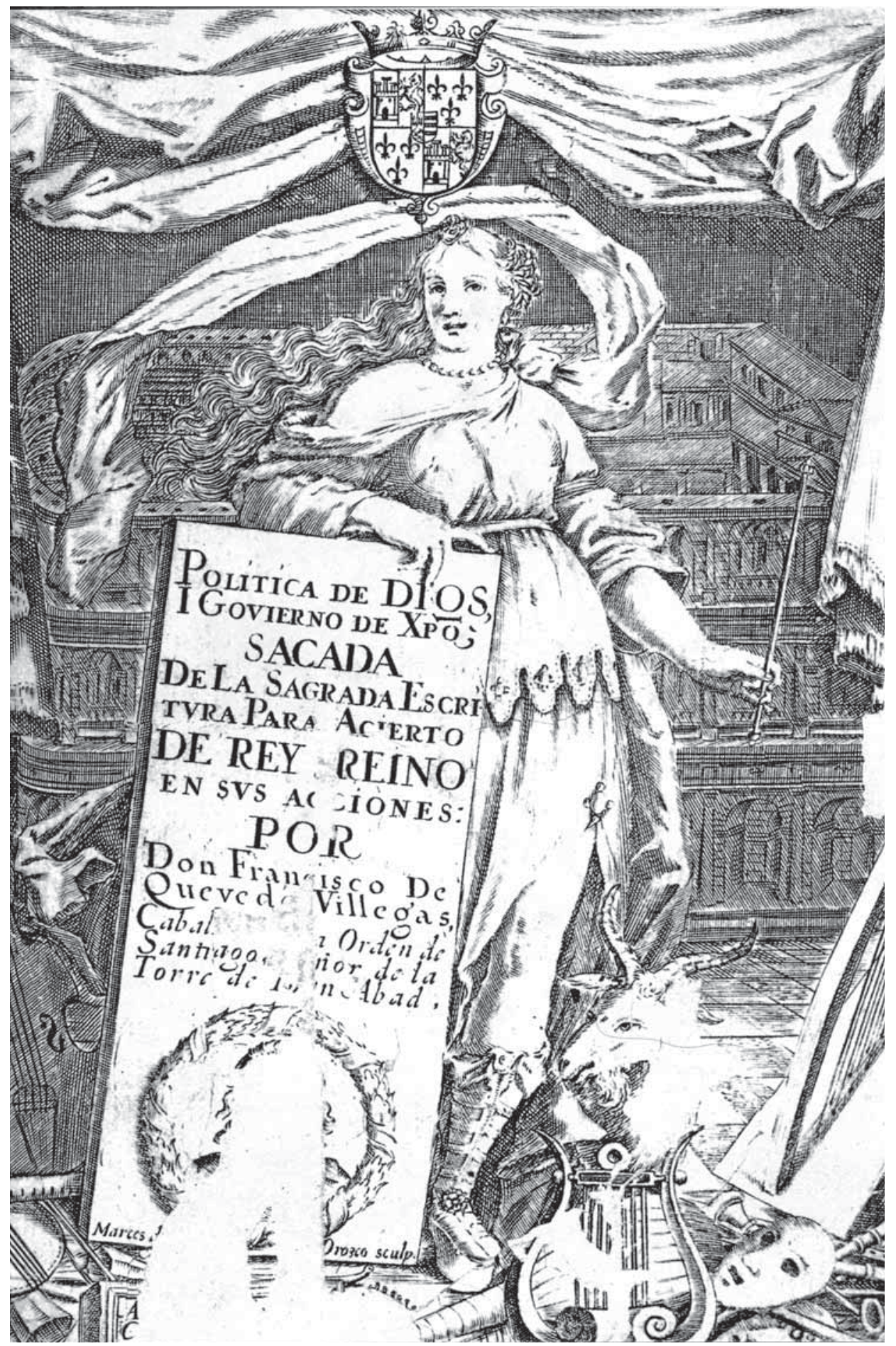

Fig. 12. Francisco de Quevedo. Política de Dios, y Gobierno de Cristo (ed. Madrid, Pedro Coello, 1655). Grabado de Marcos de Orozco 
que experimentaba la casa de Austria. ${ }^{81}$ Así, desde las primeras páginas muestra el escritor su preocupación por la pesada carga de la monarquía, con afirmaciones como «reinar es velar. Quien duerme, no reina» (primera parte, capítulo X); o «el reinar no es entretenimiento, sino tarea, que los cetros piden más sudor, que los arados» (primera parte, capítulo XVI). Se revela -aunque con matices- como enemigo del descanso real al afirmar que Dios encomendó el reinado al monarca no para el ocio, sino para el trabajo y afán diarios; de ahí también su despiadada crítica hacia todo aquel que incline al monarca a la comodidad y descanso, pues «quien divierte al rey le depone, no le sirve» (primera parte, capítulo IV). La advertencia al monarca es clara: «sospechosos deben ser a los reyes, señor, los solícitos de su comodidad y descanso, pues su oficio es cuidado». ${ }^{82}$ Debemos interpretar estas palabras a la luz del contexto de la época, cuando desde muchos sectores se acusaba al conde-duque de Olivares de entretener a Felipe IV con juegos, amoríos y otras distracciones poco acordes con su oficio de rey, y cuando ya a comienzos de la década de 1630 -recordemos que la segunda parte de la obra data de 1635- se había producido el distanciamiento de Quevedo respecto de la política del valido.

Numerosos ejemplos dio Cristo de actitud vigilante, algunos de los cuales desgrana Quevedo en el capítulo X de la primera parte, entre ellos el de la oración en el huerto mientras los discípulos dormían. Mas es en el capítulo XIII de la segunda parte donde aborda en profundidad cuál ha de ser el descanso de los reyes en medio de la penosa fatiga del reinar; y en su reflexión se sirve del relato evangélico de la samaritana narrado por Juan. Al igual que Cristo descansó de la fatiga corporal del camino, pero comenzó a esforzarse en la andadura espiritual de la salvación de un alma, así también los reyes que imitan al Señor deben descansar de un trabajo con otro mayor. De manera que, cuando el monarca se encuentra cansado tras los despachos, audiencias o consultas de los Consejos, debe forzosamente dedicar un tiempo al ocio y al descanso; pero este no consistirá en pasatiempos vanos, sino en el servicio de sus súbditos, atendiendo las quejas de los agraviados para impartir justicia en sus reinos. Esté por tanto atento a las costumbres, intenciones y necesidades de su pueblo, pues la vigilancia será bálsamo y medicina que le otorgarán el verdadero descanso y la fama como rey. ${ }^{83}$

81. José Luis Aranguren: «Lectura política de Quevedo», Revista de Estudios Políticos, T. XXIX, 1950, 158-159.

82. Quevedo se muestra muy crítico con aquellos que persuaden al monarca para que se abandone al descanso y al ocio, pues considera que en realidad tratan de usurpar las obligaciones reales. Así lo recoge en diversos capítulos de la segunda parte de su obra: «El Ministro que dice al monarca: no trabaje tanto en sus despachos; no padezca tan prolijas audiencias; no se aflija con los sucesos desdichados; no se inquiete por remediarlos; apártese esto de V. M., y todo lo que no fuere ocio, y entretenimiento. Pues Señor, a este (llámese como quisiere) los reyes, en oyéndole estas palabras, Satanás le han de llamar, y mandarle ir lejos» (cap. IX); «Quien os dice, Señor, que desperdiciéis en la persecución de las fieras las horas, que piden a gritos los afligidos, ese más quiere cazaros a vos, que no que vos cacéis» (cap. XIII); «Quien al lado de los Reyes atiende al descanso del Rey, y a su comodidad, ese el mal ladrón es, porque le hurta la honra y el premio, y el logro de su cargo» (cap. XIV). Politica de Dios, y Govierno de Christo, 345, 359 y 367.

83. Peraita, Quevedo y el joven Felipe IV, 179-190. 


\section{LA NEGACIÓN DEL DESCANSO REGIO}

Finalmente, un grupo más reducido niega al rey cualquier tipo de descanso. Coinciden parcialmente en su planteamiento con quienes defienden el «descanso activo», pero resultan más categóricos al rechazar de plano la posibilidad del descanso, ni siquiera entendido este como cambio de actividad útil y provechosa a sus súbditos; tal actitud, por dura que parezca, le granjeará el mayor premio al que puede aspirar un monarca, como es el amor de su pueblo, y la fama y la gloria inmortales. El sol que nunca deja de comunicar sus benéficos rayos, la columna que siempre permanece firme, o el león vigilante que duerme con los ojos abiertos, son algunas de las imágenes de las que se sirven en su negación del descanso regio.

En este grupo se inscribe el capellán real Cristóbal Lozano, autor a mediados del siglo XVII del Alivio de lastimados, David Perseguido, en cuyo capítulo XXIII de la tercera parte da cuenta de los últimos cuidados del rey veterotestamentario, que consistieron en dejar sucesor en su corona y disponerse a bien morir, lo cual lo convierte en ejemplo para los monarcas españoles. Aprovecha también Lozano para extenderse en diversas consideraciones en torno al descanso en el oficio de reinar, del que se muestra contrario, por cuanto «aun en la cama doliente, e impedido le van a buscar a un Rey desvelos, pesadumbres y cuidados... Por dulce que sea el reynar, si ha de acudir un Rey a lo que debe, no ha de tener un rato de descanso». Pero, en continuo desvelo por sus súbditos, éstos lo reconocerán como padre, tal y como ocurrió con algunos antepasados en la monarquía española como Alfonso I, Fernando I de Castilla, Fernando III el Santo, o el emperador Carlos V; y ahí radica el verdadero descanso del monarca, en el amor filial de sus súbditos. ${ }^{84}$

Apenas dos décadas más tarde se expresará en parecidos términos Pedro de Avilés, miembro del Santo Oficio que desempeñó diversos cargos al servicio de $\mathrm{Su}$ Majestad. En 1673 se publican sus Advertencias de un político a su príncipe, obra concebida en tono laudatorio hacia el virrey de Nápoles Antonio Álvarez Osorio, en quien observa todas las virtudes y cualidades que debe poseer el rey. El Discurso Segundo del tratado discurre acerca de «Que es mayor el trabajo, que tienen los Príncipes mandando, que los Vasallos obedeciendo»; y se muestra categórico al afirmar que «ser Rey no es para gozar de gloria, y delicias, sino para padecer penas, y trabajos. El gobernar un reino no da lugar al sueño ni al descanso». No obstante, los desvelos del monarca por el bien común tendrán su merecido premio, y este será el de la alabanza pública y aclamación de todos sus súbditos. ${ }^{85}$

84. Parte Tercera de David perseguido, y Alivio de lastimados. Historia sagrada, parafraseada con exemplos, y varias Historias, Humanas, y Divinas... Escrita por el Doctor Don Christoval Lozano, Comissario de la Santa Cruzada... En Madrid: En la Oficina de Antonio Marin. Año de 1733, 329.

85. Advertencias de un politico a su Príncipe observadas en el Feliz Govierno del Excelentísimo Señor D. Antonio Pedro, Alvarez, Osorio, Gomez, Davila, y Toledo. Marqués de Astorga, Virrey y Capitan General del Reyno de Nápoles, etc. Ofréceselas al Señor Don Antonio de Guzmán, Sobrino de su Excelencia, y su Teniente de la Compañía de Lanças en este Reyno D. Pedro de Avilés, familiar del S. Oficio de la Inquisición... En Nápoles por Novelo de Bonis Impressor Arch. 1673, 8-16. 
También los libros de emblemas niegan la posibilidad del descanso al rey, si bien es cierto que en ocasiones el concepto de descanso puede llegar a confundirse con el de ocio o pérdida de un tiempo que debiera dedicarse al gobierno de la monarquía. Contemporánea a la obra de Avilés es el David Pecador del dominico Antonio de Lorea, espejo de príncipes mediante el cual trata de fijar una serie de máximas políticas a la luz de la doctrina cristiana, por cuanto «ser Rey, y regir Reinos, y naciones, es cosa tan dificultosa, que arte para gobernar se ha de pedir a Dios», declara en su prólogo al lector. Precisamente por seguir la vida del rey David, el tema del descanso en el monarca adquiere especial relevancia en su obra, como lo demuestra el hecho de dedicarle el discurso I del capítulo I, en el que refiere el principio y ocasión del pecado de David. El emblema que lo ilustra lleva por mote In otium labores (Contra el ocio, trabajo), y muestra dos columnas que emergen del mar sobre cuyos capiteles descansan sendas coronas; alrededor de sus fustes se enroscan filacterias con la inscripción plus en la columna izquierda, y ultra en la derecha [Fig. 13]. Quiere dar a entender con ello que el oficio de rey implica el cuidado constante de su pueblo, por lo que el monarca debe huir del ocio y la comodidad; así lo hizo el emperador Carlos V al sustituir el Non Plus Ultra de las columnas de Hércules por Plus Ultra, indicando que sus trabajos deben ir más allá de lo que otros juzgan posible. No merece título de rey quien abandona sus obligaciones y se entrega al descanso, por cuanto la ociosidad tan solo produce deshonra; y, en consecuencia, será justo castigo que otro mande en el reino y se lleve las glorias de vencedor. ${ }^{86}$

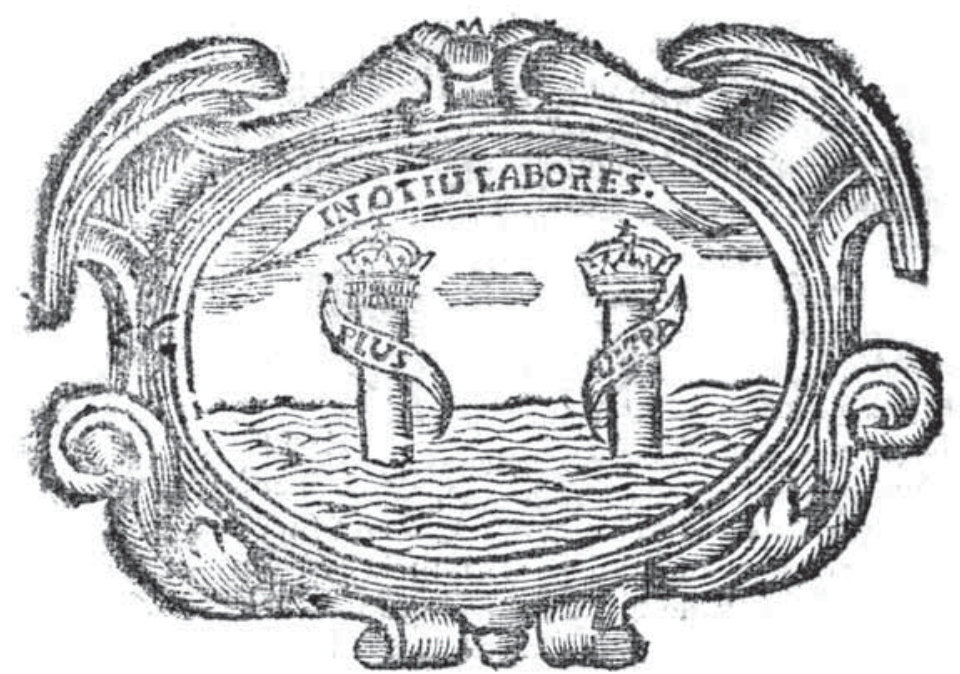

Fig. 13. Antonio de Lorea. David Pecador. Capítulo I, Discurso I: In otium labores

86. David pecador, Enpresas Morales, Politico Cristianas, compuestas por F. Antonio de Lorea, Coronista General de la Orden de Predicadores... Año 1674. En Madrid, por Francisco Sanz, 6-22. 
Apenas una década más tarde, Juan Francisco Fernández de Heredia, caballero de la Orden de Alcántara y miembro del Consejo Supremo de Aragón, se refiere en diversas ocasiones al descanso del monarca en sus Trabajos, y afanes de Hércules, obra dirigida a Carlos II. En general se muestra contrario al mismo, pues el oficio de reinar no admite momentos de ocio ni distracción. Así lo refleja en el emblema 37, que lleva por mote Plus in virtute roboris, quam in monte (Más fortaleza hay en la virtud que en una montaña). Su pictura muestra a Hércules a modo de Atlas, caminando con dificultad y oprimido por el peso del orbe que soporta sobre sus hombros, metáfora del monarca que sustenta sobre sí una gran responsabilidad, de manera que su comportamiento no debe permitirle el descanso de sus tareas hasta el punto de que otros ocupen su lugar o lo compartan [Fig. 14]. El trabajo es el fundamento de su reinado, de manera que «a los Príncipes se les cae el Cetro, y la Corona en el ocio, y descanso», afirma. Estar atento a todo cuanto ocurre en su reinado -la vigilancia del «cetro con ojos»-, ese será el verdadero descanso del rey: «Ver con cien ojos, oír con tantos oídos, dar, y executar con cien manos suyas, y de Ministros, es su oficio, que si descansan unas, trabajan otras», concluye el emblemista. Así se condujeron entre otros Carlos V y Felipe II, quienes no perdían momento alguno en el descanso, dedicados al trabajo perenne. ${ }^{87}$

Todavía insiste el autor en su emblema 50, que con el mote Solus amor vicit Alcidem (Solo el amor venció a Alcides) muestra a la reina Ónfale vestida con la piel de león y portando la maza de Hércules, mientras este, prendado de su belleza al punto de olvidar su valentía, hila con el huso mientras Cupido se dispone a lanzar sus flechas [Fig. 15]. Mediante la figura de Hércules sometido a la tiranía del amor de Ónfale, se previene al monarca para que evite las pasiones que pueden vencer su valor y arrastrarlo a la vanidad. El descanso del monarca deberá ser el trabajo, pues lo presentará con reputación ante sus súbditos; por el contrario, el descanso entendido como ocio y deleites de la vida, acabará por transformarlo en un esclavo y precipitará su reino a la destrucción. ${ }^{88}$

Curiosamente, ambos episodios mitológicos contaban con representaciones cercanas a la monarquía hispana: el primero de ellos, mediante todo un conjunto de imágenes alegóricas que abarcan la pintura y el tapiz, el grabado y el arte efímero, a través de las cuales Hércules se convierte en metáfora de la propia monarquía como ha puesto de manifiesto recientemente Teresa Zapata; ${ }^{89}$ y el segundo, en el desaparecido lienzo Hércules y Ónfale pintado por la italiana Artemisia Gentileschi y recibido en el Alcázar en 1629, el cual

87. Trabajos, y afanes de Hercules... De Don Iuan Francisco Fernández de Heredia, Cauallero del Orden de Alcantara, del Consejo de su Magestad en el Supremo de Aragon. En Madrid: Por Francisco Sanz, Impressor del Reyno. Año de 1682, 350-360.

88. Trabajos, y afanes de Hercules, 465-474.

89. Teresa Zapata Fernández de la Hoz: «Atlas-Hércules. Metáfora del poder y gobierno de los Austrias», ZafrA, R. y AzAnzA, J. J. (eds.): Emblemática trascendente. Hermenéutica de la imagen, iconología del texto, Sociedad Española de Emblemática, Universidad de Navarra, Pamplona, 2011, pp. 785-797. 
mostraba al héroe «hilando entre unas mujeres, con un Cupido que indica lo que está haciendo», y que según el inventario de 1636 se encontraba en la «nueva habitación sobre el vestíbulo y entrada principal del Palacio», es decir, en el Salón de los Espejos. ${ }^{90}$

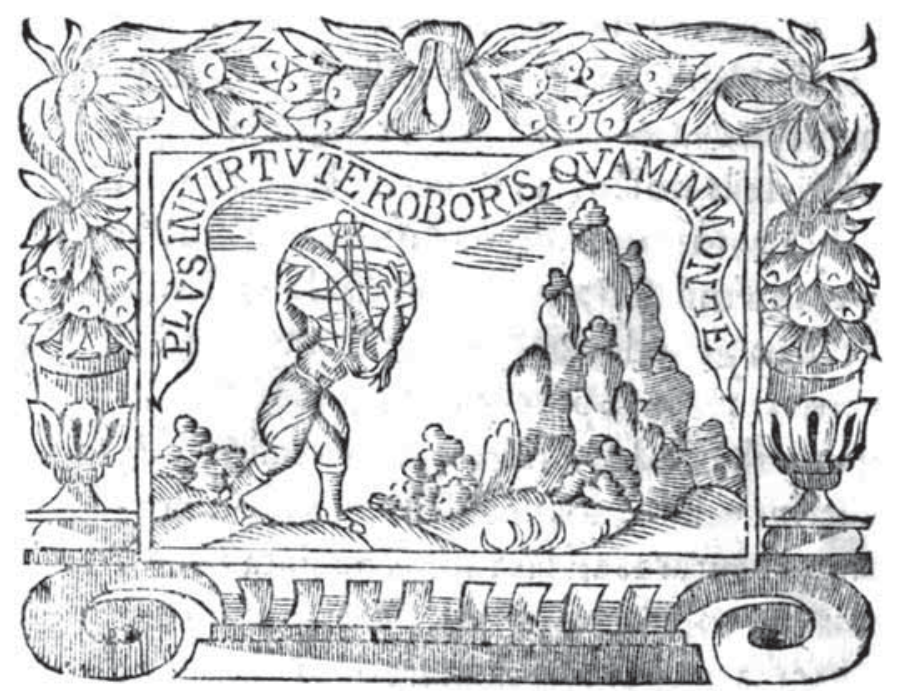

Fig. 14. Juan Francisco Fernández de Heredia. Trabajos, y afanes de Hércules. Emblema 37: Plus in virtute roboris, quam in monte

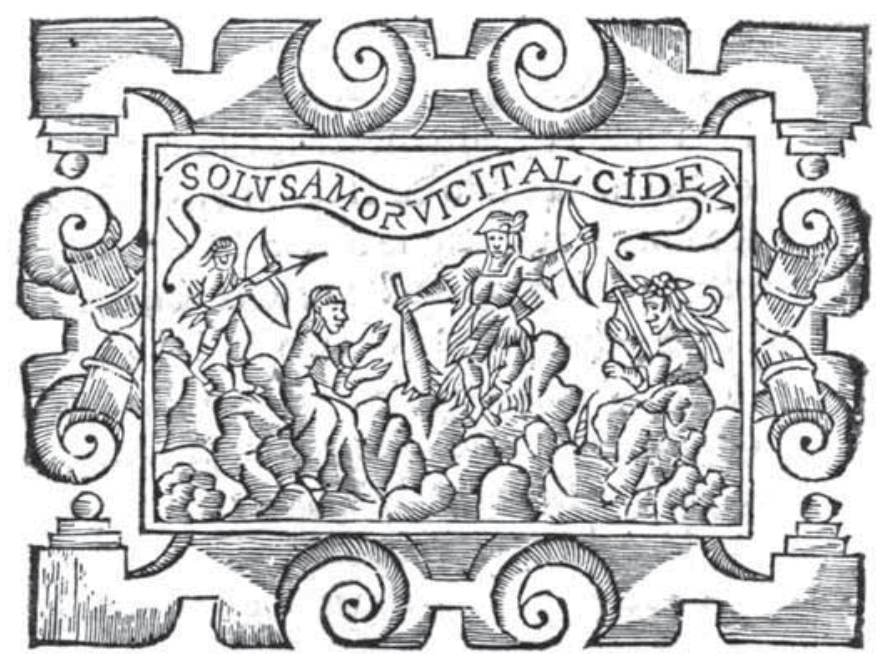

Fig. 15. Juan Francisco Fernández de Heredia. Trabajos, y afanes de Hércules. Emblema 50: Solus amor vicit Alcidem

90. Steven N. Orso: Philip IV and the Decoration of the Alcázar of Madrid, Princeton University Press, Princeton, 1986, 55, 109-110 y 190. El Real Alcázar de Madrid. Dos siglos de arquitectura y coleccionismo en la corte de los Reyes de España, 393. David garcía Cueto: Seicento boloñés y Siglo de Oro español: el arte, la época, los protagonistas, Centro de Estudios Europa Hispánica, Madrid, 2006, 195 y 197. 


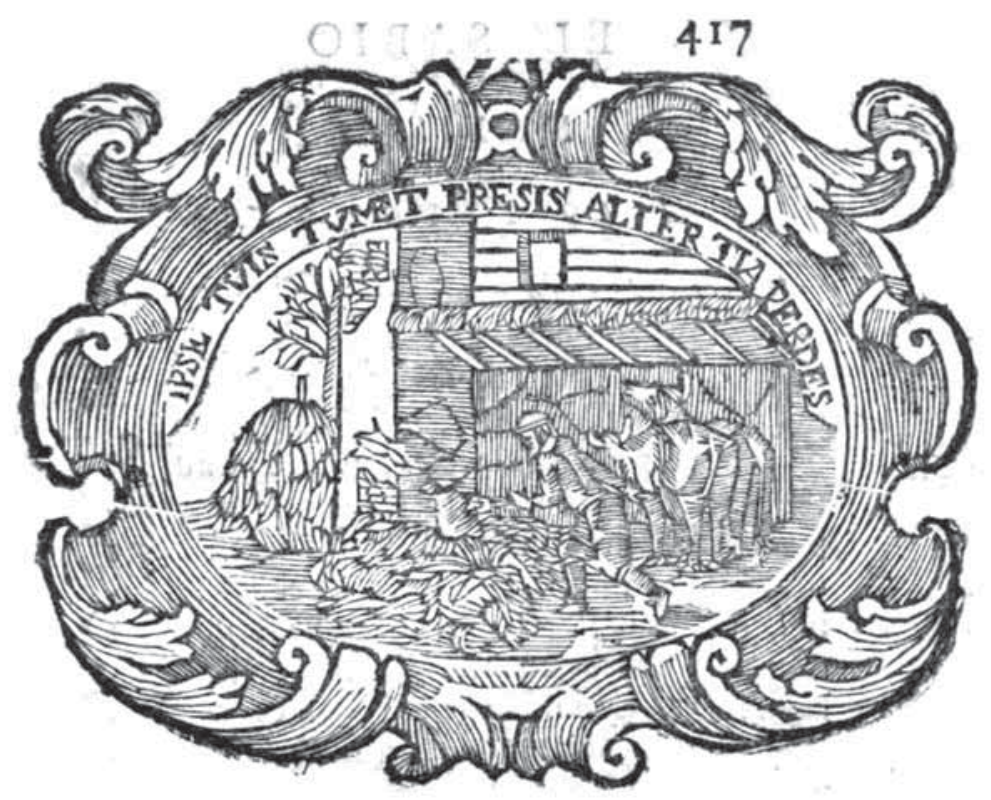

Fig. 16. Francisco Garau. El sabio instruido de la naturaleza. Ficción XXXVIII: Ipse tuis tumet presis alier tia perdes

También se refiere al descanso del monarca, al despuntar el siglo XVIII, Francisco Garau, en su obra El sabio instruido de la naturaleza, en cuarenta máximas políticas y morales, que articula en un conjunto de fábulas inspiradas en Esopo a las que denomina «ficciones». ${ }^{91}$ La ficción XXXVIII lleva por mote Ipse tuis tumet presis alier tia perdes y su pictura recoge la fábula del ciervo que, huyendo de los cazadores, buscó refugio en un establo de bueyes; y aunque ni el criado ni el administrador de la finca se percataron de su presencia, sí lo hizo el amo, que ordenó su muerte [Fig. 16]. De aquí deduce Garau la necesidad de que el monarca asista a los reinos por sí mismo y no a través de ministros, actitud que exige esfuerzo, trabajo y sacrificio, y es en este punto donde teoriza acerca del descanso del monarca. Se sirve para ello de algunos ejemplos del firmamento, pues los cielos nunca descansan si no es en su movimiento, y tampoco el sol tiene un momento de alivio, ya que continuamente transmite su luz y calor a las criaturas para vivificarlas. De igual forma, no hay más descanso para el monarca que la fatiga y el desvelo por sus vasallos, pues «lo que son para los hombres trabajos y fatigas, son naturaleza y desahogo, más que molestia en los reyes». Ahora bien, el premio compensará con creces la «honrada esclavitud»

91. El Sabio instruido de la naturaleza, en Quarenta máximas políticas, y morales, ilustradas con todo género de erudición sacra, y humana. Por el R. P. Francisco Garau, de la Compañía de Iesus... En Barcelona, por Rafael Figverò Impressor. Año 1702, 417-432. Sobre la influencia de Esopo en Garau, véase ANTONIO BERNAT VISTARINI: «Emblema in fabula: El sabio instruido de la naturaleza, de Francisco Garau», Los días del Alción. Emblemas, Literatura y Arte del Siglo de Oro (eds. Antonio Bernat Vistarini y John Cull), José J. de Olañeta, Palma de Mallorca, 2002, 83-91. 
en que consiste el reinar sin descanso, por cuanto le dará la fama inmortal y le permitirá disfrutar de la vida eterna.

Hemos tenido oportunidad de comprobar en Fernández de Heredia y Garau que la metáfora solar es una de las más recurrentes a la hora de negar la posibilidad de descanso al monarca. El sol -dice Picinelli- es emblema que se aplica principalmente a aquellos que se entregan al trabajo incansable y continuamente. ${ }^{92} \mathrm{~A}$ ella acude también el escritor y orador jesuita portugués Antonio Vieira con idéntico propósito, pues al igual que Dios hizo al sol príncipe del mundo (Génesis 1, 16), y desde el día en que le dio este oficio, no ha descansado un momento, así también el rey deberá trabajar sin descanso, incluso cuando sus vasallos duermen, pues para quien gobierna y manda siempre es de día. El reloj, sustituto del sol en la tierra, que solo suena en determinados tiempos pero cuyas ruedas siempre están en movimiento, y el león, rey de los animales, que duerme con los ojos abiertos en su vigilia permanente, completan las imágenes propuestas por Vieira para negar al monarca el descanso en su conclusión: «El que sirve, por dura que sea su servidumbre, siempre tiene horas de alivio, y descanso; el que manda, ninguna $»{ }^{93}$ Digna de mención es la imagen del león como símbolo de vigilancia continua, motivo muy antiguo derivado del convencimiento de que este animal duerme con los ojos abiertos. A partir de los textos clásicos como la Historia de los Animales de Claudio Eliano, será recogida en diversos repertorios emblemáticos, como los de Horapolo, Alciato, Pierio Valeriano o Zincgreff. ${ }^{94}$ En el ámbito español pueden citarse los Emblemas morales de Sebastián de Covarrubias, quien en el emblema 23 de su III Centuria muestra, con el mote Pervigilant ambo (Ambos velan), un león frente a un conejo, el primero imagen del príncipe que vela siempre por la tranquilidad de sus súbditos; ${ }^{95}$ y también Saavedra Fajardo lo recoge en la empresa 45 de sus Empresas Políticas, con el mote Non maiestate securus (No por la majestad seguro), para dar a entender al príncipe que ha de vigilar y hacer creer a todos que está siempre en vela, incluso cuando duerme ${ }^{96}$ [Fig. 17].

92. Filippo Picinelli: El Mundo Simbólico, Libro I. Los Cuerpos Celestes (eds. Bárbara Skinfill Nogal y Eloy Gómez Bravo), El Colegio de Michoacán, Zamora, 1997, 192.

93. Se trata del sermón de San Roque publicado por Vieira al rey Juan IV de Portugal en la Capilla Real de Lisboa en el año 1652. El V. P. Antonio de Vieyra de la Compañía de Jesús. Todos sus sermones, y obras diferentes, que de su original Portugués se han traducido en Castellano... Tomo Tercero. Barcelona: En la Imprenta de Juan Piferrer, Año 1734, 165-166.

94. Arthur Henkel y Albrecht Schöne: Emblemata: Handbuch zur Sinnbildkunst des XVI und XVII Jahrhunderts, Metzler, Stuttgart, 1996, cols. 399-401.

95. Emblemas Morales de Don Sebastián de Covarrubias Orozco, 223.

96. Idea de un Príncipe Político Christiano, 287-290. SA Avedra FajArdo, Empresas Políticas, 540-544. 


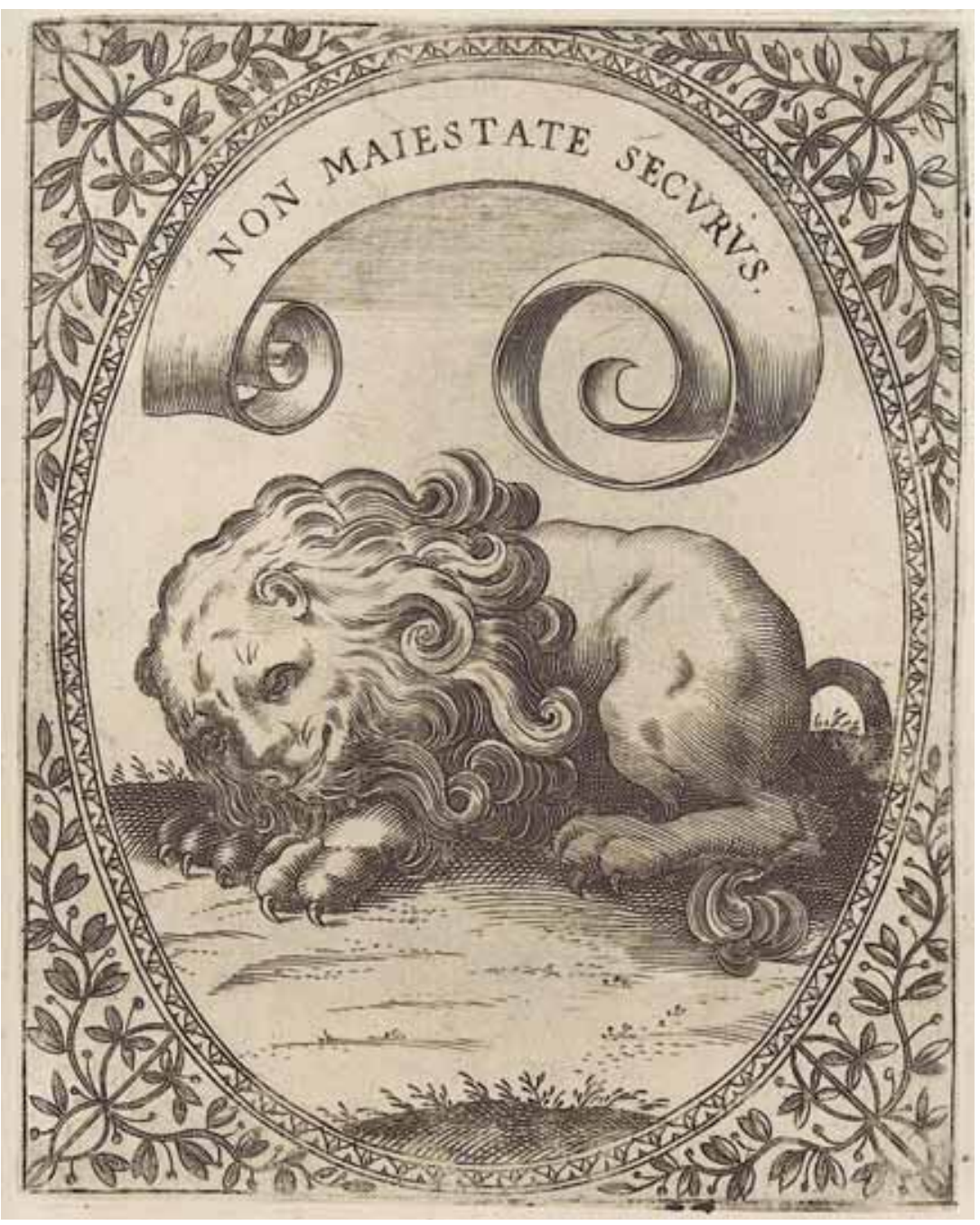

Fig. 17. Diego Saavedra Fajardo. Idea de un príncipe político christiano. Empresa 45: Non maiestate securus

\section{CONCLUSIÓN}

El anterior recorrido por autores y obras pone de manifiesto que el tema del descanso regio no resultó ajeno al pensamiento político hispano de la Edad Moderna, dadas las implicaciones que conllevaba y que afectaban a la esencia misma de la monarquía; descanso que fue objeto de formulaciones diversas y en ocasiones encontradas por parte de teóricos y moralistas.

Una vez sentadas las bases teóricas, son múltiples las posibilidades de abordar el descanso del monarca desde su aplicación práctica. De esta manera, resultaría de interés comprobar la inserción del descanso en la etiqueta y ceremonial de palacio, para ver cómo se conjuga con el arte de gobernar y con 
los entresijos de la política palaciega por parte de quienes trataban de alejar al monarca de sus obligaciones, en un intento por controlar y asumir la labor regia. Asimismo, conviene no olvidar que la monarquía genera un modelo de conducta social que se extiende a un amplio sector de la alta nobleza, que hace suyas la estética y las pautas de comportamiento real, por lo que deberíamos analizar si el descanso regio en alguna de sus variantes participó de esta suerte de imitatio. E igualmente habría que contemplar la idea del descanso en correspondencia con las distintas formas de entender la relación entre los reyes y sus reinos, para comprobar cuál era la imagen que agradaba más a sus súbditos: ¿la del rey que a través de las actividades de ocio y descanso podía mostrarse a todos y hacerse más cercano, o la del rey que sin tiempo para el reposo se desvela por ellos con actitud vigilante?

Convendría asimismo perfilar el descanso regio -entendido en la primera de las variantes que aquí hemos mostrado- en el marco de la celebración festiva de la corte, que Castiglione presentaba como un provechoso ejercicio de conversación e ingenio, salpicado con alguna pequeña chanza y complementado con algo de música y baile. Porque, no cabe duda, el rey se divertía, ajeno muchas veces al lamento de sus súbditos por el hambre y la guerra, o al separatismo territorial que amenazaba con destruir la hegemonía hispana. ${ }^{97}$ Según se defendía desde sectores cercanos al monarca, las fiestas y espectáculos cortesanos iban encaminados a desterrar los agobios de las responsabilidades del gobierno regio, y a alegrarlo con la risa, dado que el pesado oficio real entrañaba gravedad y tristeza, y producía un exceso de humor seco que era necesario combatir; fiestas que se convertían a su vez en un remedio para el cansancio y melancolía de los cortesanos, abrumados igualmente por las tareas de gobierno. La fiesta, en definitiva, era un paliativo del mal de gobernar que afecta al rey, pero también a los cortesanos, que encontraban en ella su descanso. ${ }^{98}$ Recordemos por último que poblaban la corte muchos que buscaban hacer del ocio un negocio: ¿cómo contemplaban éstos el descanso del monarca? Cuestiones todas ellas abiertas sin duda a futuras investigaciones.

97. No podemos dejar de citar en un trabajo de esta naturaleza la pionera obra de JosÉ DelEITO Y Piñuela: El rey se divierte (recuerdos de hace tres siglos), Espasa-Calpe, Madrid, 1935, a propósito de Felipe IV.

98. En esta dirección encamina Fernando Bouza algunos de sus clarificadores trabajos, entre los que destacamos «Cortes festejantes. Fiesta y ocio en el cursus honorum cortesano», Manuscrits, 13, 1995, 185 203; y «El rey a escena. Mirada y lectura de la fiesta en la génesis del efímero moderno», Espacio, Tiempo y Forma, Serie IV, Historia Moderna, t. 10, 1997, 33-52. 


\section{FRÖMMIGKEIT UND RitTERORDEN. EIN NeUer Blick AUf Die JohanNiter IN DER BALLEI BRANDENBURG}

Agnes Baumert

Universität Potsdam

Zusammenfassung: Der Beitrag untersucht die Frömmigkeitspraxis der Johanniterordensballei Brandenburg (14.-16. Jh.). An ausgewählten diplomatischen Quellen, die den Frömmigkeitsformen der Stiftungen, Ablässe, Verbrüderungen und liturgischen Bestimmungen zugeordnet werden, wird mithilfe der religionssoziologisch ausgerichteten Frömmigkeitsforschung die Bedeutung des Johanniterordens als Seelsorgeorden in der spätmittelalterlichen Frömmigkeit herausgearbeitet. Die Johanniter traten zu verschiedenen Personenkreisen -Einzelne und Gruppen, Laien und Klöster- in Beziehung, mit denen sie ihnen angetragene und ordenseigene Frömmigkeitsbedürfnisse organisierten und umsetzten. Die Frömmigkeitspraxis des Ordens ist nicht nur durch seine soziale Umgebung geprägt, sondern auch ein Indikator für die Anpassung an den nordostdeutschen Raum, den der Johanniterorden seit Mitte des 12. Jh. vornahm.

Schlagworte: Johanniterorden, Ballei Brandenburg, Frömmigkeitspraxis, Spiritualität, Ritterorden.

ABSTRACT: This article examines the heretofore little known practice of piety of the Hospitaller order in the bailiwick Brandenburg (14$16^{\text {th }}$ c.). Selected diplomatic sources are sorted according to forms of piety like foundations, indulgences, fraternities, and liturgical norms. Together with socio-religious piety research they are the grounds for the enquiry of the importance of the Hospitaller as an order of pastoral care. The order was in contact with various groups and individuals, with laypersons and cloisters, organising their and the order's aspiration to piety. 